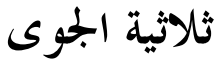 \\ (التشابه والاختلاف في البنية والختنوى)
}

\section{حنان حمودة}

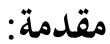

الثلاثية قصائد ثلاث أنشدها ثلاثة شعراء من أبرز الشعراء الإسلاميين في العصــر

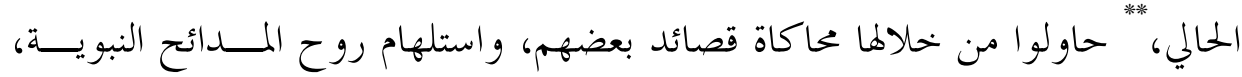

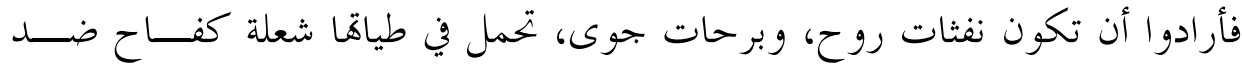

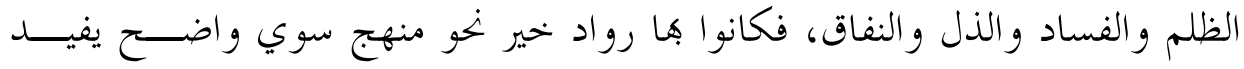

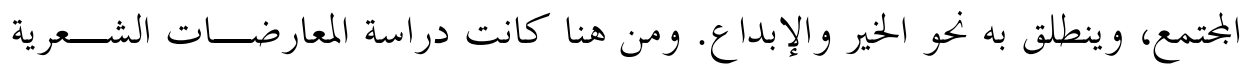

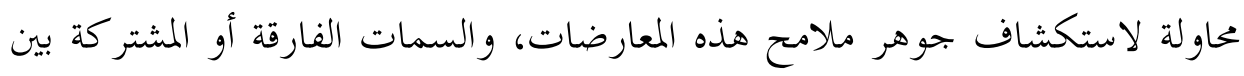
الشعراء المتعارضين، وهذا يتأتى بالدرس و التحليخليل.

وإذا كانت المعارضات غالباً ما تكون بين شاعرين متعاصرين أو غير متعاصرين،

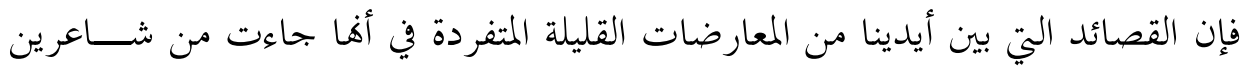

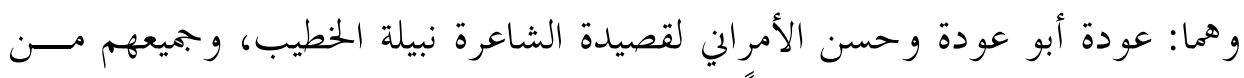

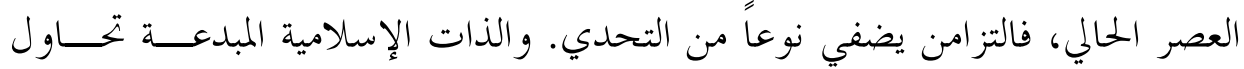

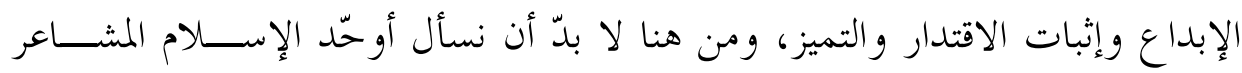

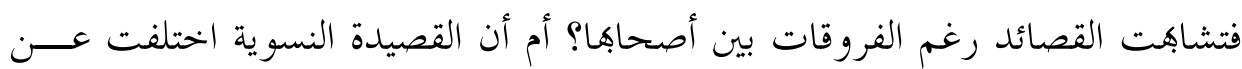

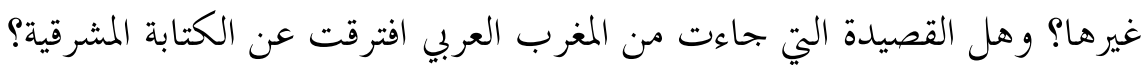
ولإجابة عن هذه التساؤلات لا بدّ من وقفة عند الثلاثية للبحث عــن أوجـــهـ التشابه والافتراق في المحتوى والبنية. ولهذا جاء البحث في قسمين: المحتوى والمضمون، و التر كيب و البناء.

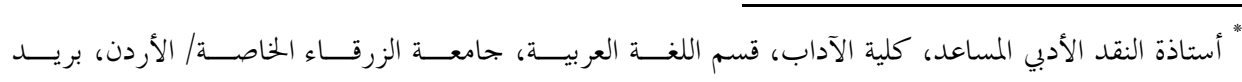
إلكتروني: hananhamoudah@yahoo.com "*** انظر القصائد الثلاث كاملة في فاية البحث. 
القصائد، موضوع الدراسة، تدع شعورك ينطلق إلى ميدان فسيح من عالم الروح الرحيب، و كما يقول سيد قطب: "الشعر تعبير عن اللحظات الأقوى والامتلاء بالطاقة الشعورية في الحياة."' فالقصائد الثلاث تو اصل روحي واضح بين الشعراء و الرســـول

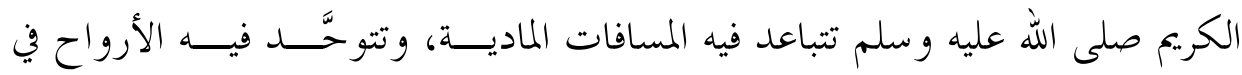
ومضات إنسانية تحاول إنارة النفس، وفتح الدروب أمامها نخو الرقـي والتســـامي في

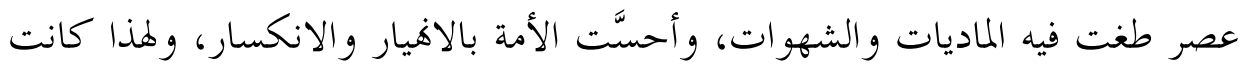

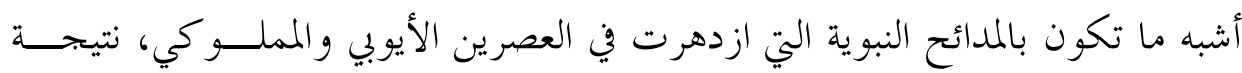

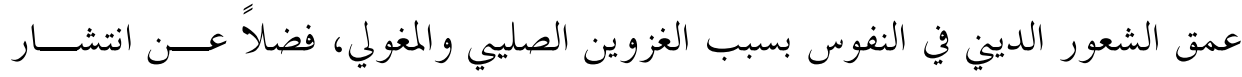

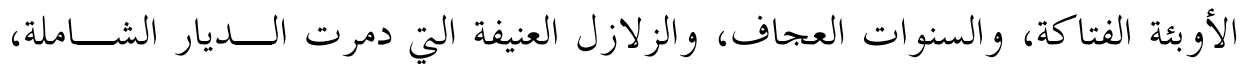

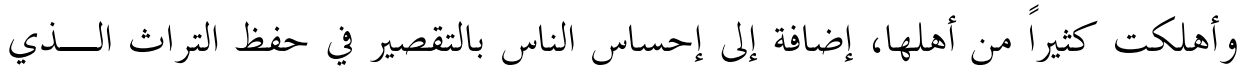

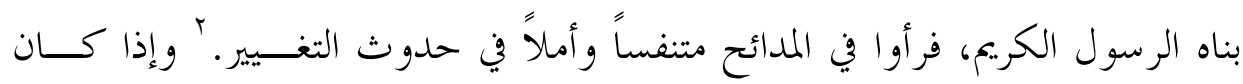
الباحثان عادل جبر، و شفيق الرقب يريان أن الازدهار كـــان في العصـــرين الصــليي و المغولي، فإن الباحث ماهر حسن فهمي يرى أن المدائح النبوية ازدهــــرت في ثــلاث مراحل هي: مرحلة الدعوة الإسلامية، ومرحلة الحروب الصليبية؛ إذ عادت المـــدائح وعلى رأسها بردة البوصيري وشروحها ومعارضاقا، وفي العصر الحديث عادت المدائح بقوة من جديد فانتشرت عند البارودي وشوقي وغيرهما، وهذا يعني أن المدائح ظلت

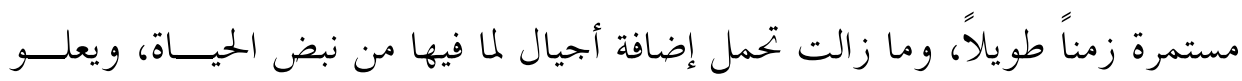

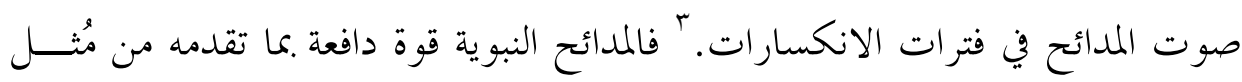

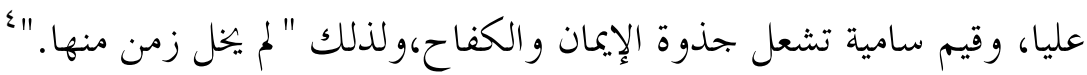

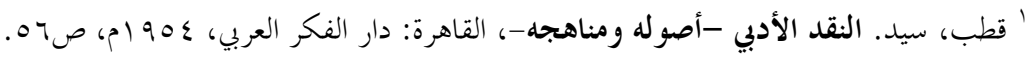

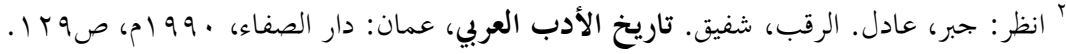

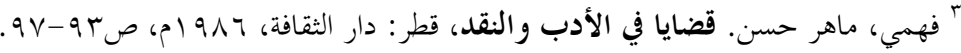

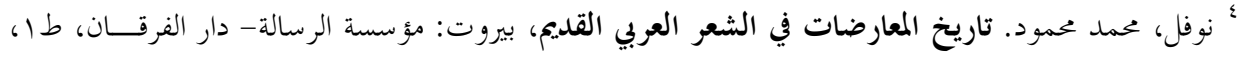




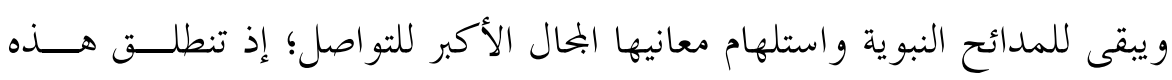

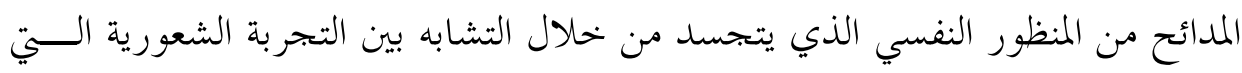

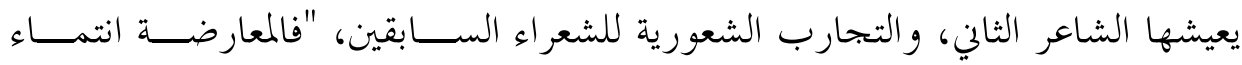

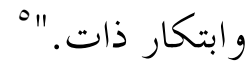

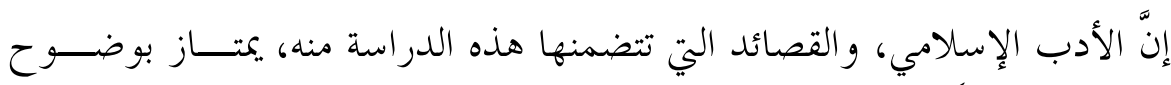

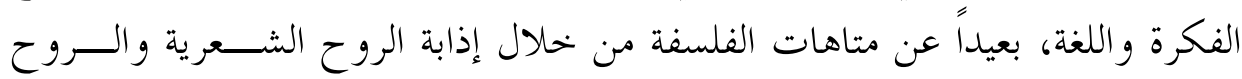

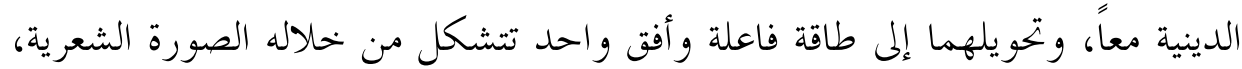

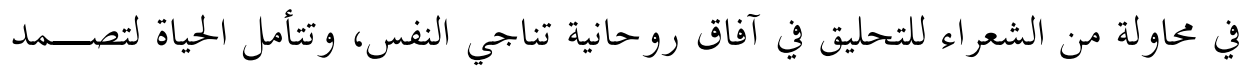

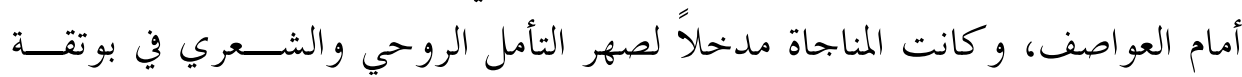

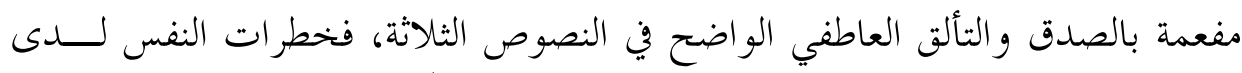

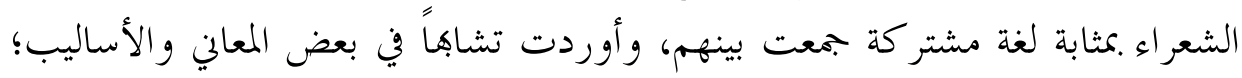

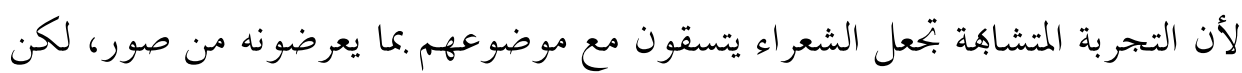

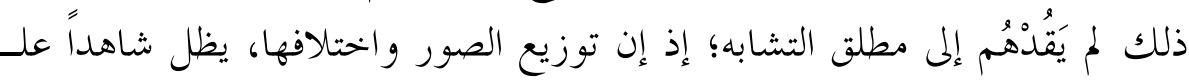

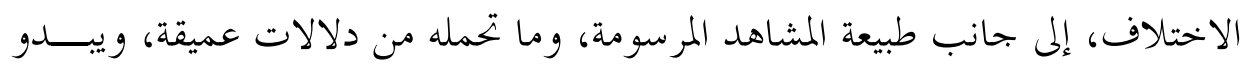

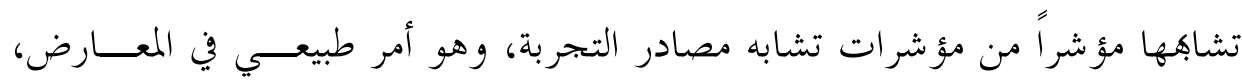
ويبدو اختلافها مؤشراً من مؤشرات إبداع الشئ الشاعر وملكته الشعرية التي ينفرد بها.

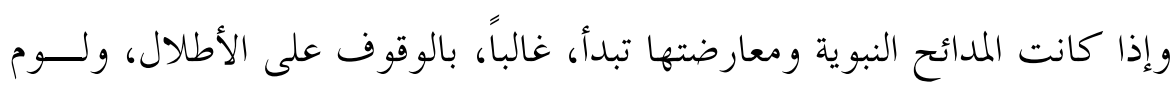

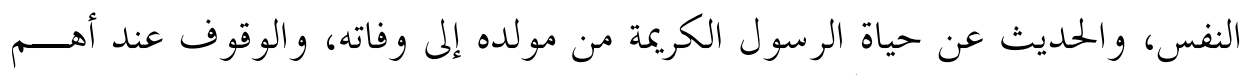

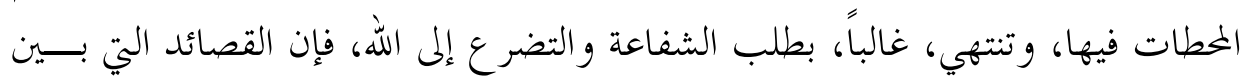

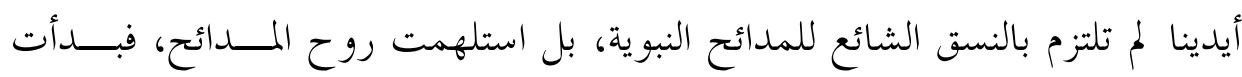

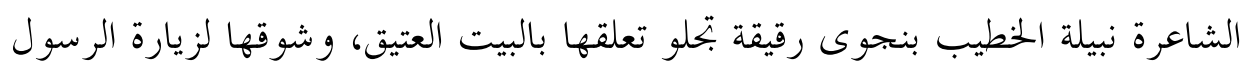

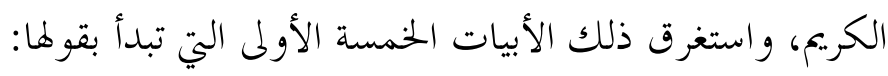
والكون إذ أنت الحبيب شـــاف

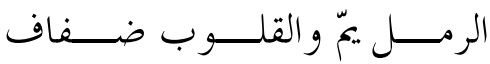


تم تحدثت عن الرسول الكريم ونسبه وخلقه في الأبيات الخمس التالية مـــن (7- آ

(1)

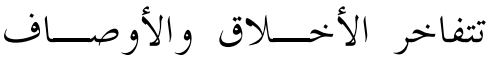

هو سيد الخلق الذي من حســــه

تم عادت للحديث عن حنينها وشوقها لزيارة الديار المقدسة من (1 (1-7 ()):

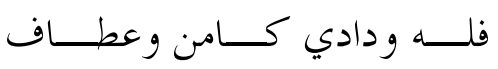

أقرئه عني ما و سعت من الجــــوى

و لم يكن مدح النبي الكريم عندها للحديث عن تاريخه، بل كان اســتنجاداً بــهـ

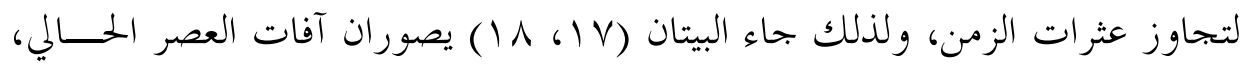

وجسدت الشاعرة ذلك بوضوح حينما قارنت الماضي البحيد بالحاضــــر في الأبيــات

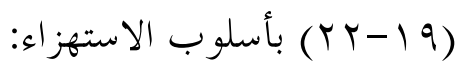

مستخلفون، و أيما اســتخلاف؟!

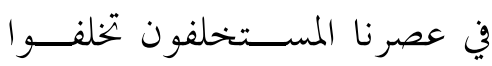

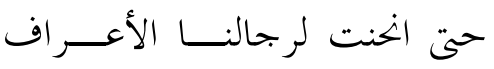

كنا بلجنا الصبح في غست الدجى

وجاءت آخر الأبيات لتحمل أملاً في مستقبل مشرق، لا يقوم إلا بيجهـــود فيـــة

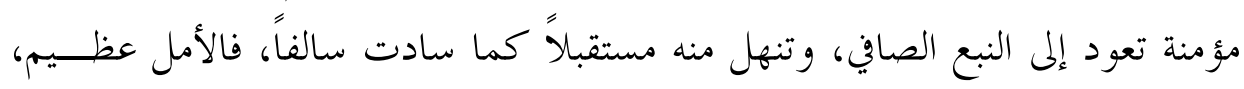
ويتضح ذلك في قولها:

إنا وقد سدنا الــــنا الأشـــــاف قلنا بمل ع الضاد - و وهي عظيمــة

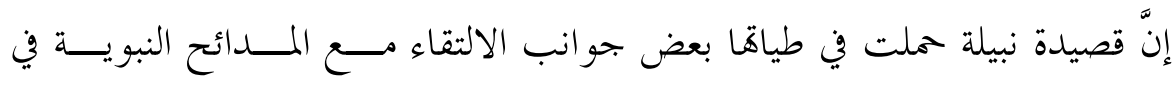

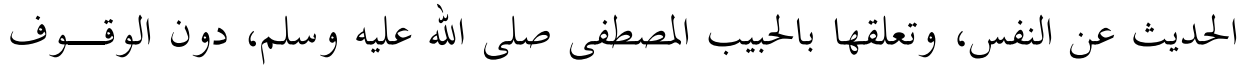

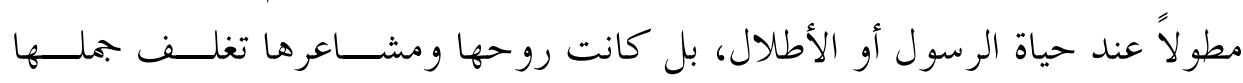
وصورها، و كان صوقا النسوي الهادئ المثقل بآلام الحاضر يبوح بآلام اليوم، ويستبطن 


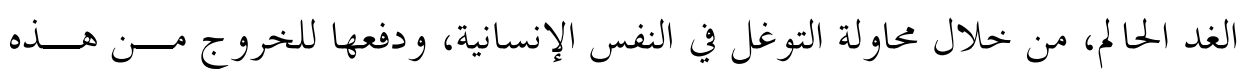

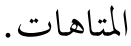

أمَّا القصيدة الثانية للشاعر عودة أبو عودة فقد بدأت بالحـــديث عــن الحبيـــبـ المصطفى صلى الله عليه وسلم، وصفاته في الأبيات الخمسة الأولى بادئاً بقوله:

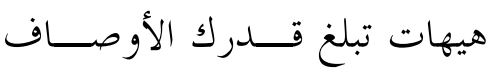

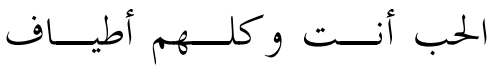

وجاء تعلقه بالماضي البحيد من (7-9) ممتزجاً بالحديث عن الرسول صلى الله عليه

و سلم:

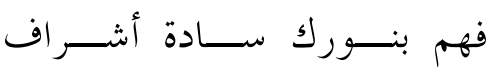

و الســـــابقون تبـــــوؤو إيمـــــــــم

تم قابل الحاضر المقيت والماضي الأثير في الأبيات (• (1-ـ ():

فاستحكم الإتلاف و الإســفاف

لكن خلفهـم أضـــاعو ا رشـــــم

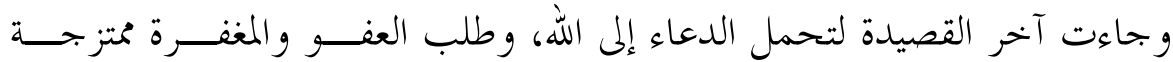

كشاعر فياضة في حب رسول الله، و الشوق إلى دياره وزيارته:

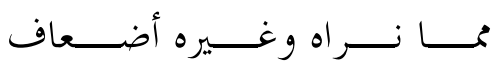

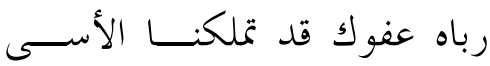

وانتهت القصيدة بالقول:

عني وعندك يكـــرم الأضـــياف

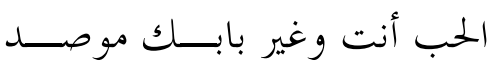

عارض الشاعر عودة الشاعرة نبيلة، فاتفق معها في المناجاة و الشـــوق إلى زيــارة

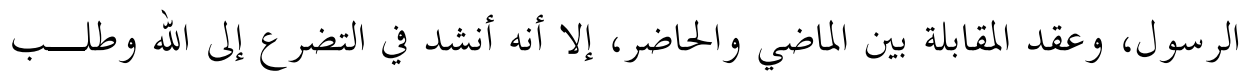


العطف مطولاً. وتلمس الشاعر الهمّ العربي الاجتماعي والسياسي، فكان الأفق عربياً،

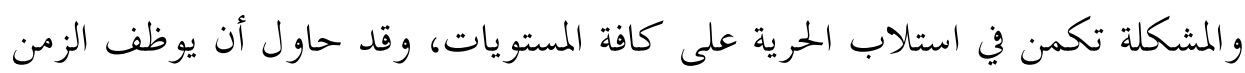

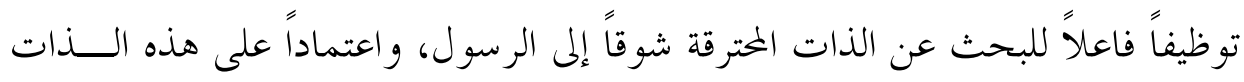

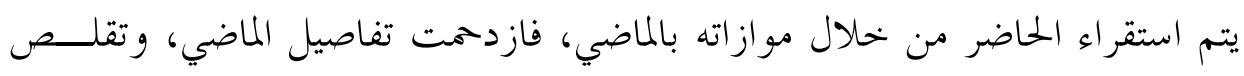

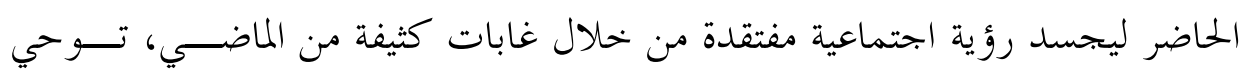
بتسلط الماضي على إحساس الشاعر ولغته.

أمَّا القصيدة الثالثة للشاعر حسن الأمراني؛ فتميزت بلوحات فنية توقظ الــنفس،

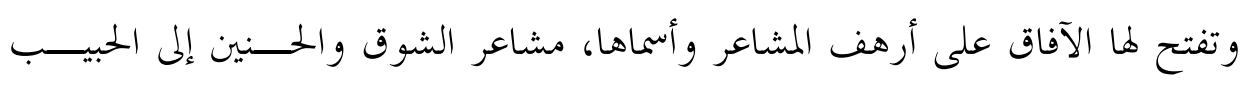

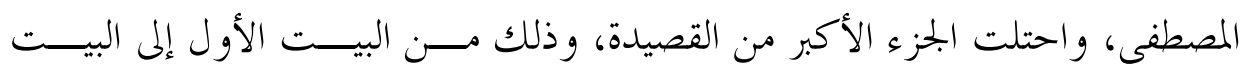
الثلاثين، و بدأها بقوله:

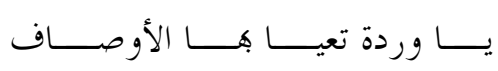

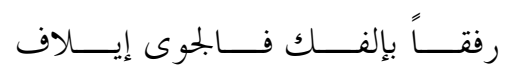

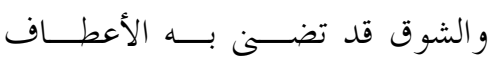

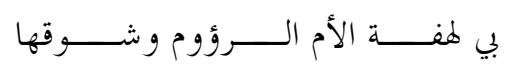

ثم انتقل لاستدعاء الماضي ليكون ملاذاً للأمة الضائعة، علّها تــــوي إلى آفـــاق

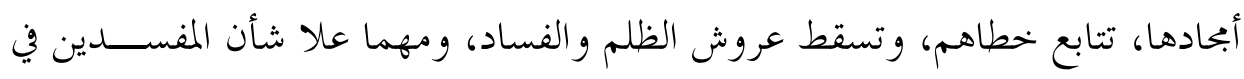

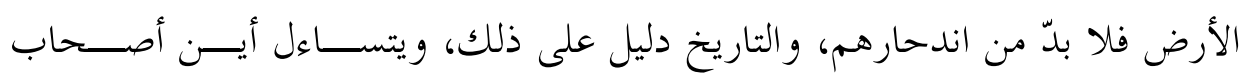

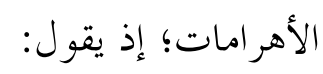

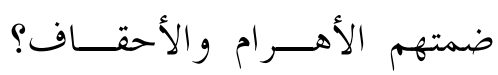

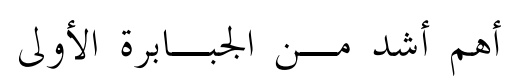

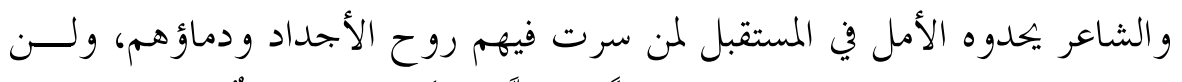

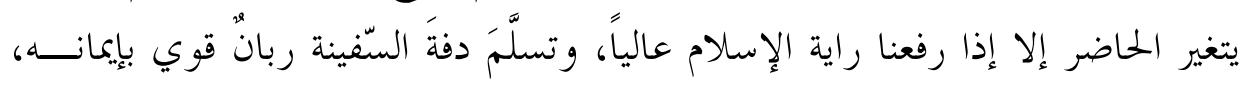
يعرف الحق ويسعى إليه، وذلك في أبياته التي يقول فيها:

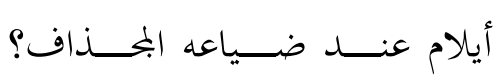
إن صار ربــــان الســـفينة تائهـــــان 


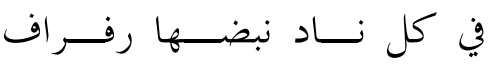

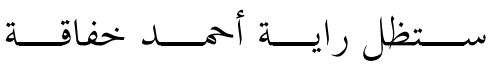

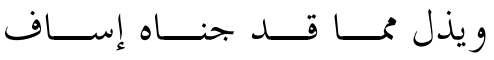

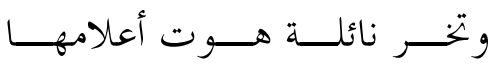

إنَّ حسن الأمراني لا يتوقف كثيراً عند سيرة الرسول صلى الله عليه وسلم، وإنَّما

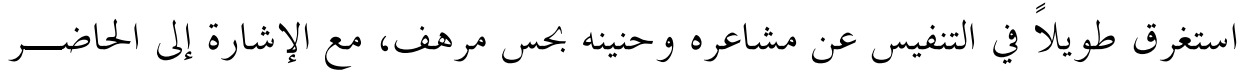

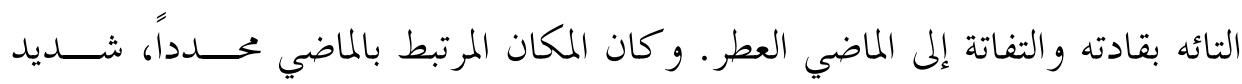

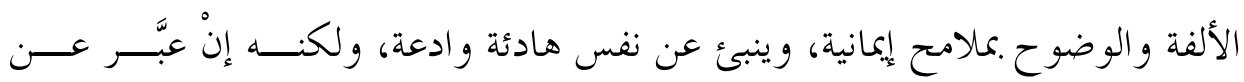
الحاضر وارتبط المكان به فقد جاء بلا ملامح، و بلا محددات، وإن تحدد فهو في مهب

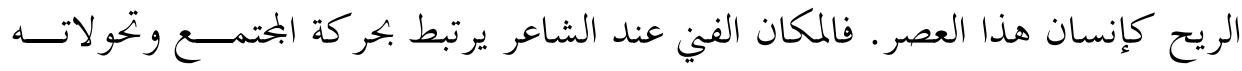
ورؤاه؛ إذ إنَّ الماضي يرتبط بـــ: (الحصون، و النخل، و الصفصاف، والبيت الحرام)، أما الحاضر فيرتبط بـــ(الزورق، والمركب، و البحر، و السفينة، والنادي)، فالثبات للماضي

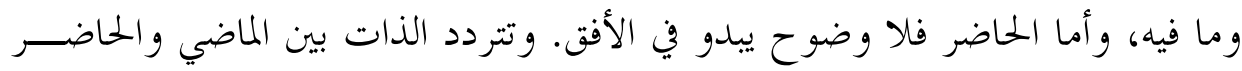
مفتقدة تفاصيل الحياة، ويبرز الوعي الثقافي العميق للمجتمع والتاريخ العربي من خلال إشارات متعددة من علامات الاستفهام، وعلامات التعجب.

و حين نتصفح هذه القصائد تستوقفنا الكلمات الطيبة النافذة إلى الأعماق؛ لأنَّها صدرت عن حس مرهف صادق، وروح إيمانية أدت إلى أن تكون معانيهم ذات طابع

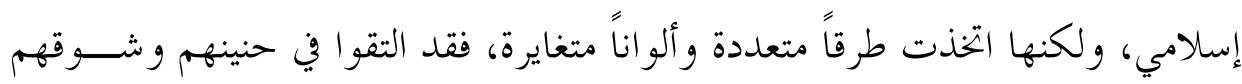
إلى الرسول المصطفى، فأطلقو العنان للشعر ليفيض بأعذب الألحان صــبابة وو.جـــــاً و ابتهالاً، مقتبسين نفحات من نور الله الذي غمر قلوبهم سناً وضياء، فسالت كلمات الشكر على ألسنتهم. إها تجربة إيمانية، ثمرة رسمت في إطار شعري يهدف إلى توعيـــة الأمة من خلال ربط الماضي بالحاضر، والاستنجاد بالرسول الكريم، خاصة أن الحاضر يشهد غفوة الأمة واستكانتها فهي الحلقة الأضعف، في حين أن الماضي ككــان لنــا، ولإعادة التوازن المختل، لا بدّ من الخروج من مأزق الحاضر بــالعودة إلى الماضــي، 
و القيم الأصيلة لتنهض الأمة من كبوةا، وتحتل مكاهـا الرائد في دنيا الحضــارة. وروح

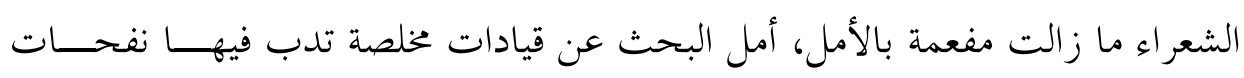

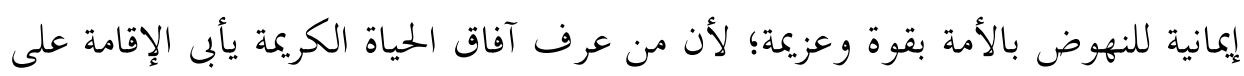
الذل، والسبيل إلى ذلك لا يكون إلا بالعودة إلى القرآن والسنة، وهذا كان الإحساس

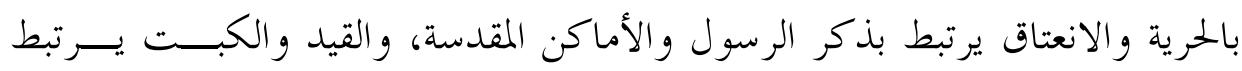
بالواقع الاجتماعي. ولذلك كان رفض الشعراء الثلاثة للحاضر خالياً من نقمة، ورلكنه

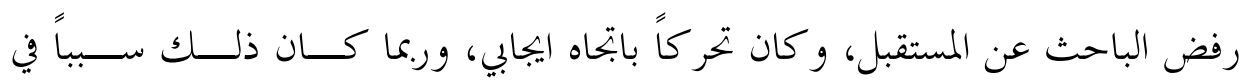

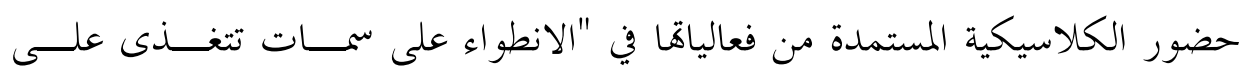

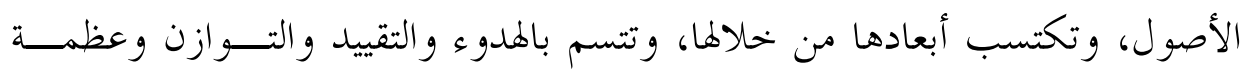
الشأن. الأصو'

وكانت الرؤية الشعرية لديهم تحاول الكشف عن الذات، واستشفاف الأســـرار،

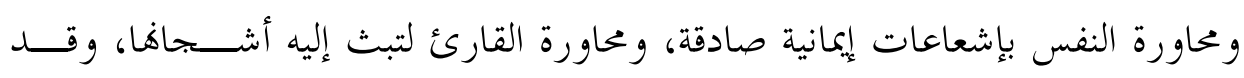
حملت في طياها إدراكاً حقيقياً للإيمان وما يتطلبه من بحاهدة النفس لتسمو و تنطلق من ونس ماديات الواقع إلى روحانيات لا محدودة، ومن هنا كان البحث عن التوازن بين الممكن واللا ممكن، وبين الرغبة و المتاح، وبين الماضي و الحاضر المتخاذل.

\section{ثانياً: التر كيب و البناء}

إنَّ الثقافة اللغوية والقدرة الفنية تتضح من خلال "رسم الشاعر لصوره الفنية التي

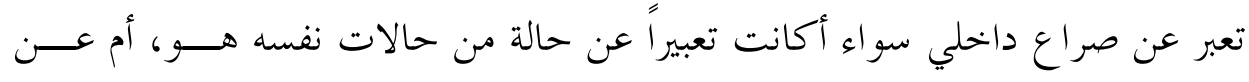

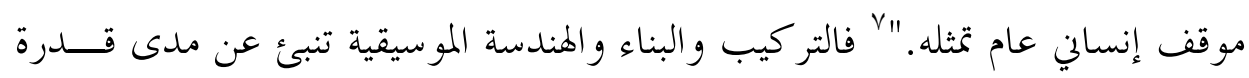




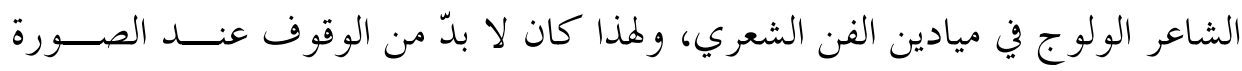

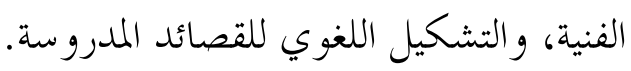

\section{1. الصورة الفنية:}

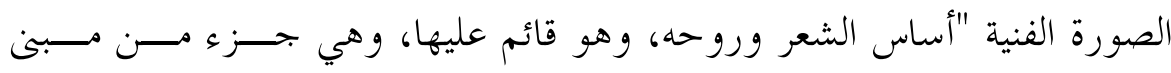

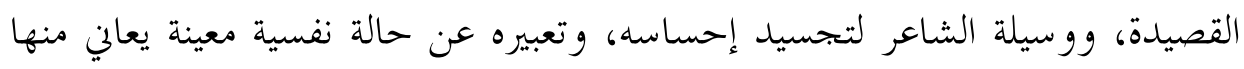

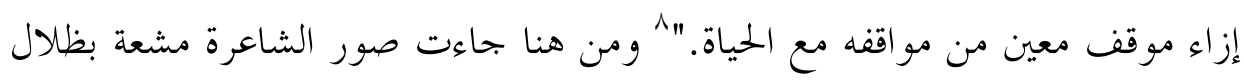

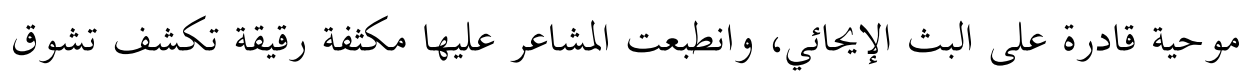
النفس، وطوقها إلى الحقى، تقول الشاعرة نبيلة:

خذني إليه وأضــلعي ابلحــــاف الموج مور دمي وشوقي مـــركبي

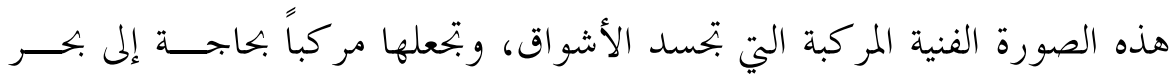

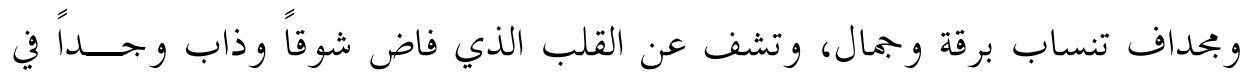

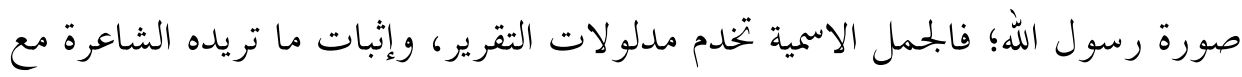

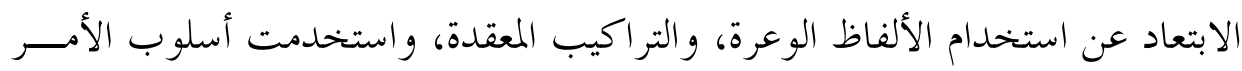

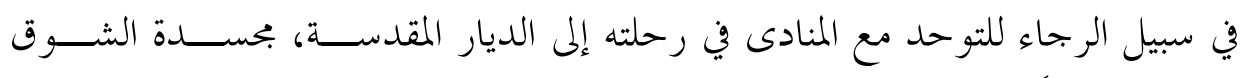

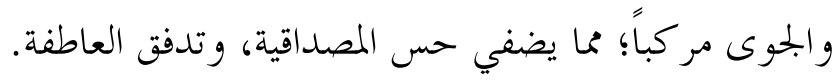

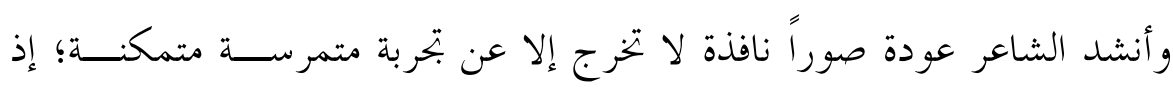
سلاسة التراكيب مع رقي الصور لا يدل إلا على امتلاك الشاعر للغته، فانظر إلى قوله:

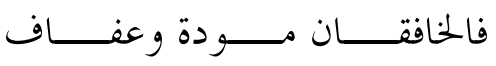
سارت مع الشمس البصائر و الهدى

إنَّنا بصدد قصيدة ارتدت ثوب البناء الفني والموضوعي، وبنح الشاعر في توظيف

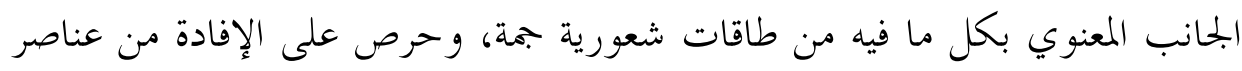

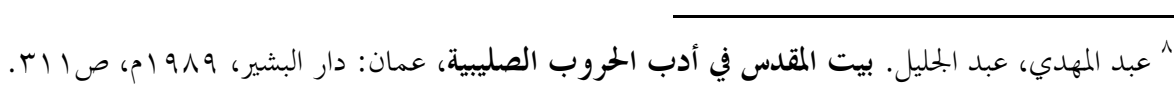


الإبداع الفني، في مقدمتها الصورة والخيال التي تميل إلى التشخيص و التجسيد كتصويره

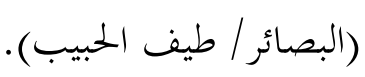

وإذا استعرضنا قصيدة الأمراني وجداناه يميل إلى الإكثار من الصور الفنية بما يفوق

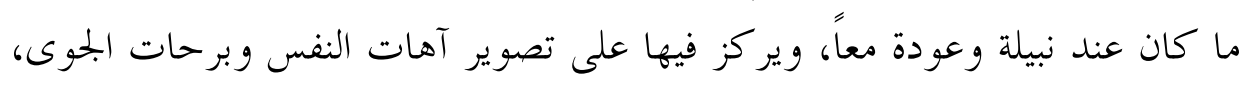
يقول:

ما تنفــع الآطــام والأسـياف

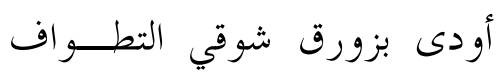

وإذا الجوى اخترق الحصون مظفراً

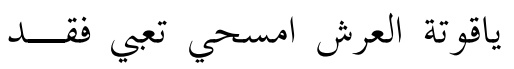

وُفّق الشاعر في امتلاك العديد من أدوات الشعر الفنية للتعبير عــن معانيـهـه عـبر

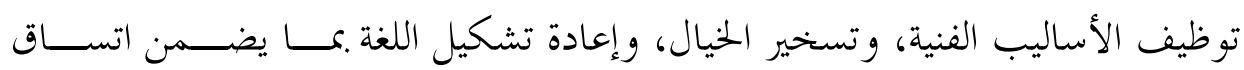

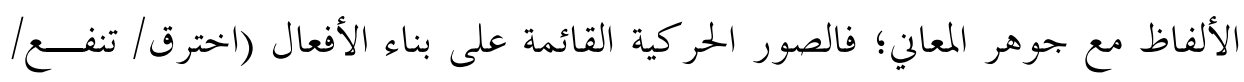

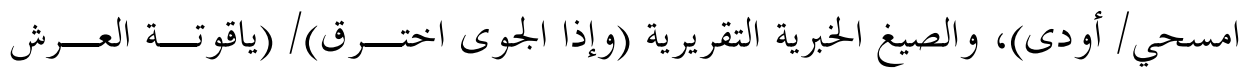

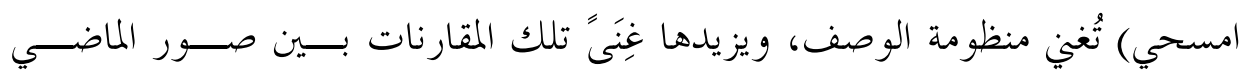

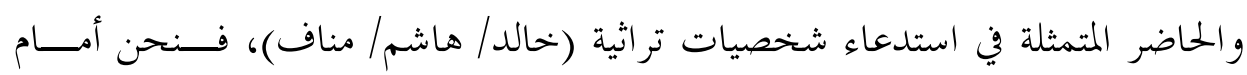

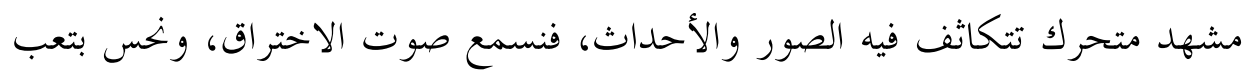
الشاعر، و ونلمسه.

إنَّ هذه القصائد يمكن أن بند فيها ما يسميه إبراهيم السامر ائي في كتابــه: لغــــة

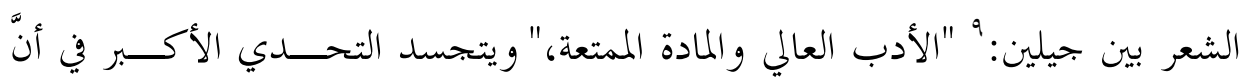

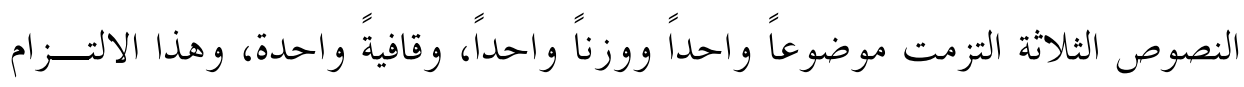

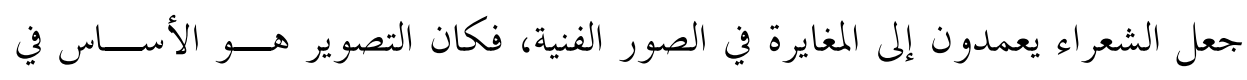

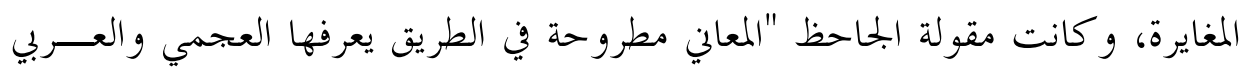

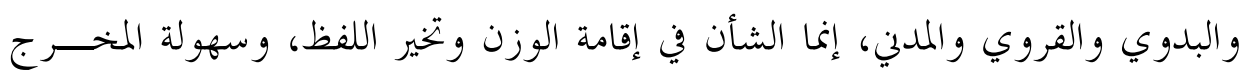


وكثرة الماء، وفي صحة الطبع وجودة السبك،" ·' تعبّر أصدق تعبير عن هذه القصــائد التي بين أيدينا؛ إذ امتد كل شاعر داخل أحاسيسه، و أنصت لها بطبع صحيح، وحوّل جر احات النفس وحنينها إلى صور ترسم بحد الماضي وتتنسم عبقه؛ ففــي القصــيدة

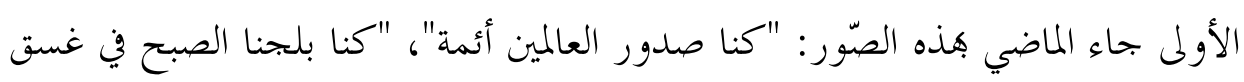

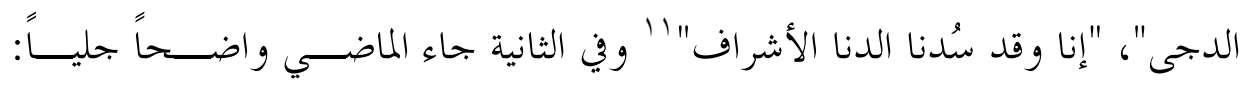

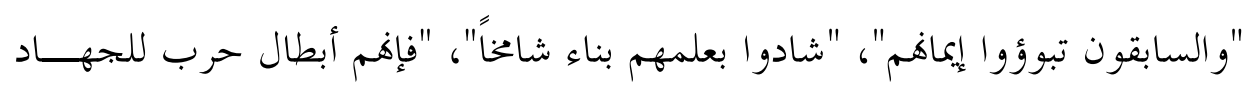

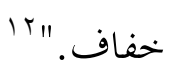

أمَّا في القصيدة الثالثة، فإن الشاعر لم يتوقف عند الماضي وأبحاده إلا من خــلال استدعاء شخوصه لنجدة الحاضر، وبيان تخاذل حكامه في قوله: "لو كان فينا خالد ما

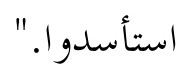
والملاحظ أنَّ كلاً من نبيلة وعودة قد أطالا الحلديث عن الشوق، وقـــابلا بــين الحاضر والماضي، في حين أنَّ الأمراني توقف عند تصوير الحنين والشوق وما يعتمل في

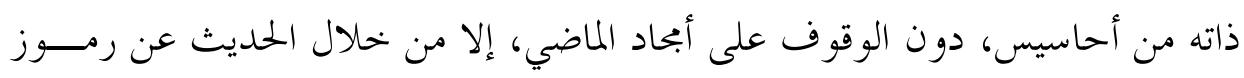
الماضي المتمثلة في: خالد وهاشم ومناف، و كانت خاتمة قصيدته ثورة علــى الفســـاد وأصحابه، ثورة يحدوها الأمل، فهو يقول:

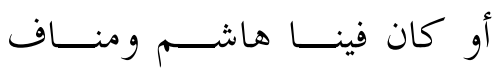

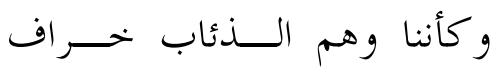

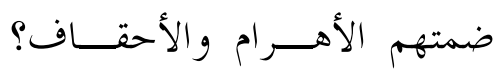

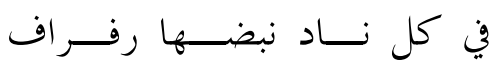

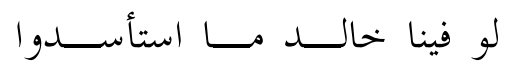

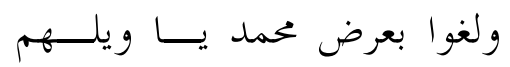

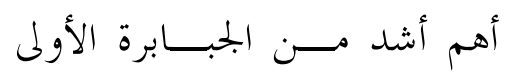

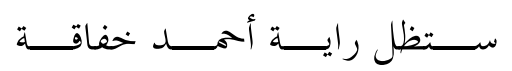

‘' الجاحظ، أبو عثمان عمرو بن بحر. الحيوان، تحقيق: عبد السلام هارون، بــيروت: دار الجيــل ودار الفكــــ،

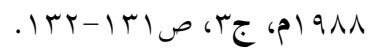

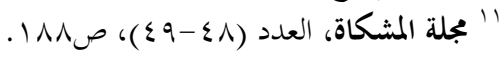

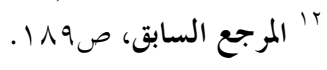


فالشاعر يعكس اغتراب الفرد، ويومئ إلى واقع مختلف عما كان عليه؛ إذ صورة

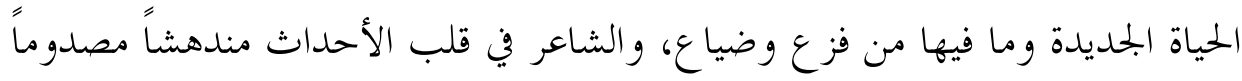
لا يصدّق ما يراه، ولا يملك سوى الأسف على ما يعاني منه الإنسان، ومن خحلال هذه الواقعية تتدفق الأحاسيس، ويطفو الوجدان على لغة الخطاب؛ ليبعث في الــنفس روح

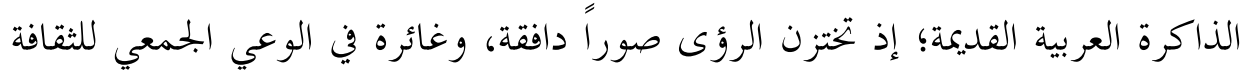
العربية، وقصص البطولة الخالدة. ويعبّر الشاعر عن تلك المعاني عبر منظومـــة عشــقـه

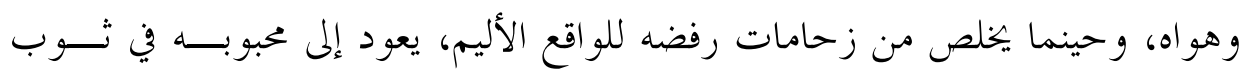

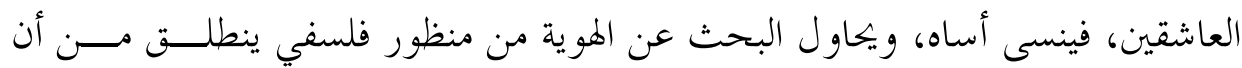

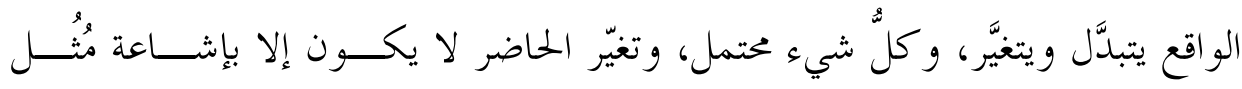

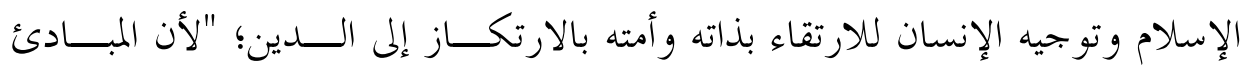

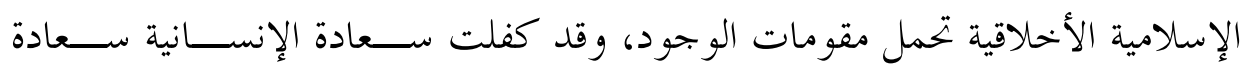

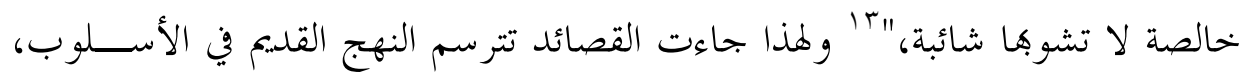

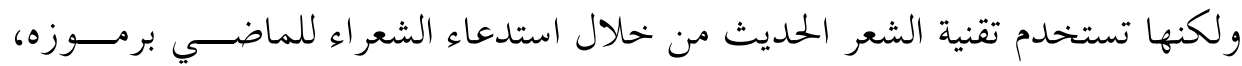
فتحدثت نبيلة الخطيب عن الماضي من خلال ذكر الأمثلة، إضافة إلى حســـيثها عــنـ أخلاق الرسول الكريم، مستشهدة بقول السيدة عائشة، رضي الله عنها، كان خلقـــه

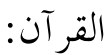

أنعــــم بــــه، و وحديثــــه إتحــــاف

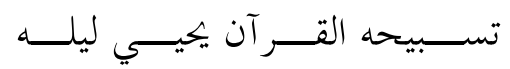

أما عودة فقد توحَّد مع المكان، وفيه يقول:

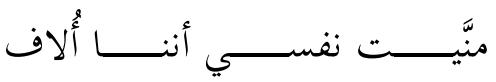

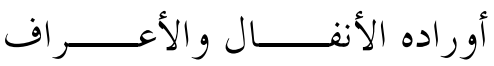

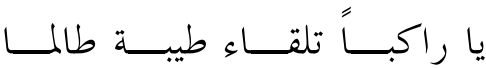

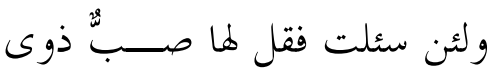




$$
\text { واستدعى رموز النور والخير والفداء حين رسم الماضي الجميل بقوله: }
$$

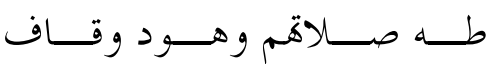

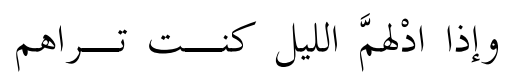

ثم نراه يستدعي رموز الجهل و الكفر فيرسم جاهلية معاصرة بقوله:

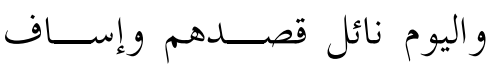

بالأمس كان الله نـــور قلــــــم

إنَّ التقابل بين العالمين الماضي والحاضر، بين الصفاء الروحي و التلوث الأخلاقـي

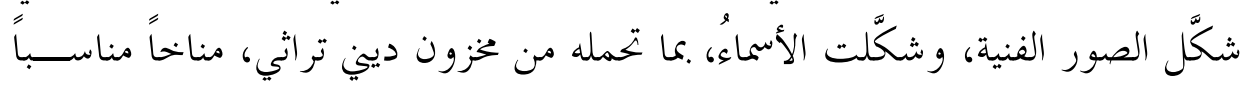

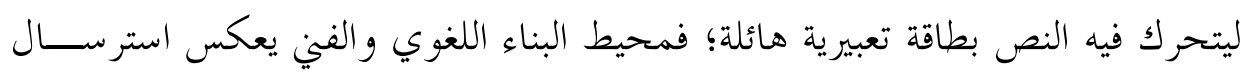

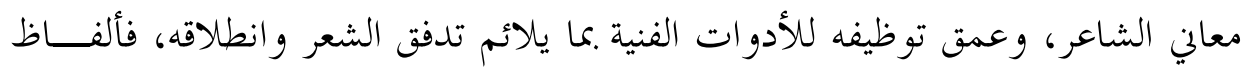

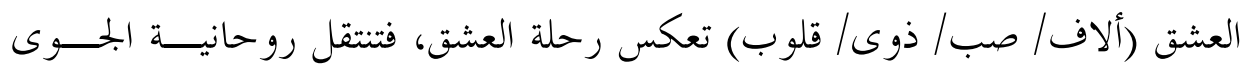

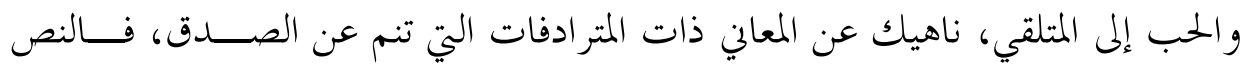

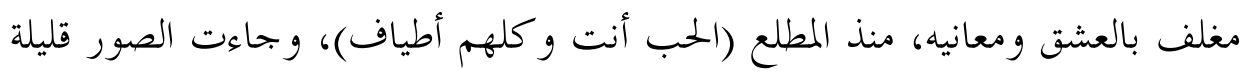
لإضفاء لمسة الواقعية على رسالته الشعورية، و الوجدانية.

أمَّا الشاعر حسن الأمراني فقد توحَّد في الزمان و المكان في قصيدته، فهو يقول:

أحد، عنت لسمائي الأشـــــاف

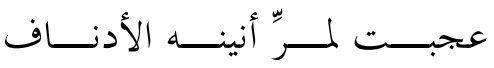

يا ليت أنّي ذرة في العشـــق مـــن

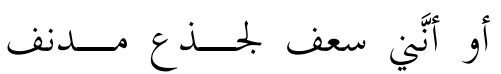

وقد استلهم من التراث شخصيات دينية بارزة لها فاعليتها وأثرها في نشر الدين،

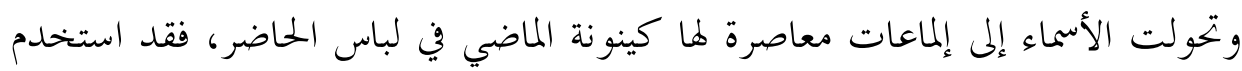

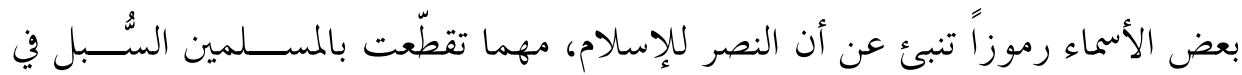

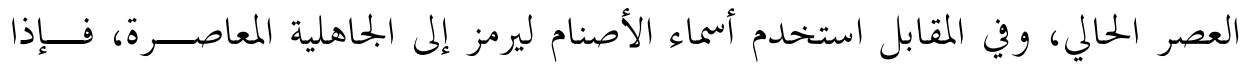

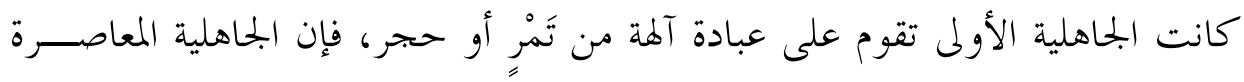


تقدس البشر فآلهتها من لحم ودم، و تعكس الصور حالة العجز عن التكيف، والتــآلف

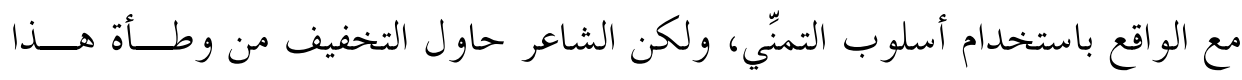

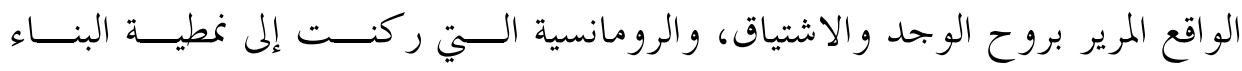

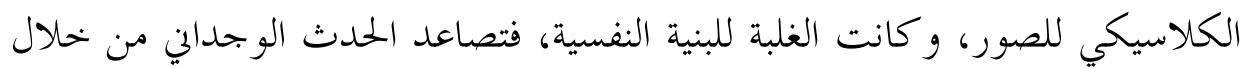
مر ادفات العشق ومعانيه.

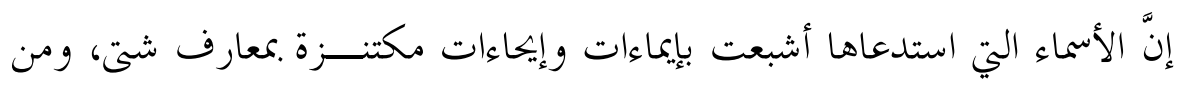
هنا جاءت كثافة الاستلهامات في قوله: أو كان فينـــا هاشــــم ومنـــاف لو كان فينا خالد ما استأســـدوا

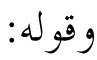

ضـــمتهم الأهـــــام و الأحقــــاف

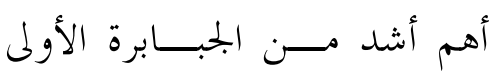

فالشاعر استطاع أن يحمّل قصيدته الأفكار والخيال بتناسق، وتناسب مميز، مــن

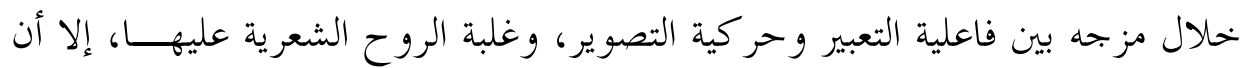
الروح الرومانسية امتزجت بخيوط الفكر، فلم يغرق في متاهات العشق، وبرع في نسج فئج

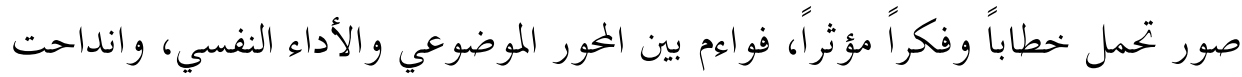

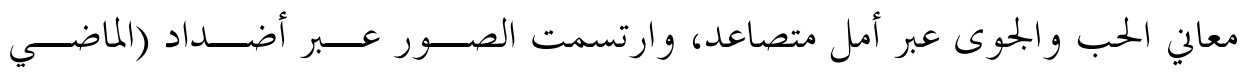

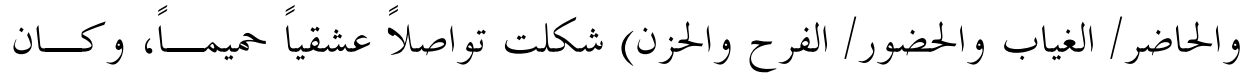

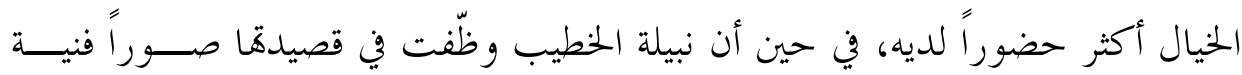
تشي بانثيال وجداني مكثف متغلغل في الذات، فجاء التعبير عــن الشــــن النفسـيـي

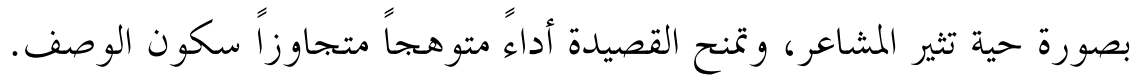

أمَّا عودة فقد بتحلت المشاعر المثارة من خلال صور تعتمد على مناجاة تتصاعد في

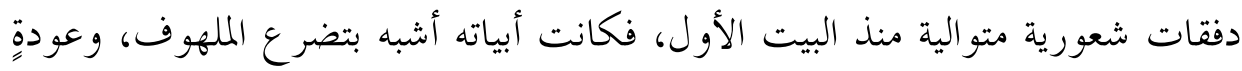


روحيةٍ إلى لحظات النقاء من خلال بساطة التعبير، والأداء النفسي الذي يمثل بحســـيداً

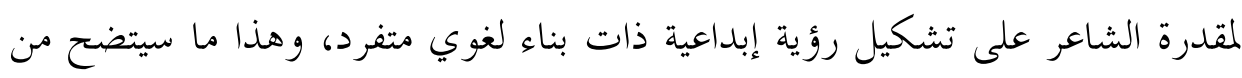

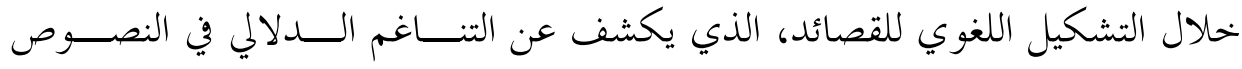

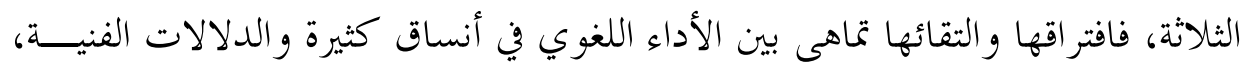

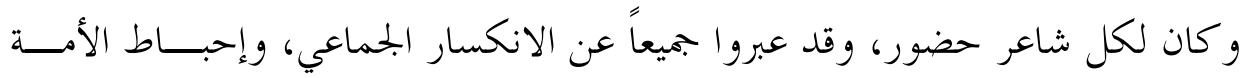
وانكسارها.

و كان أسلوب الحوار فاعلاً في التعبير عن رؤى الشعراء، فتـــد حــــاورت نبيلـــة

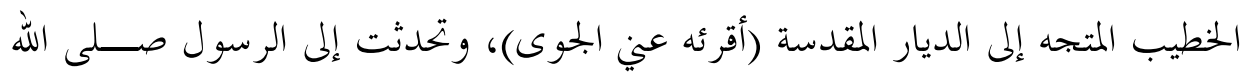

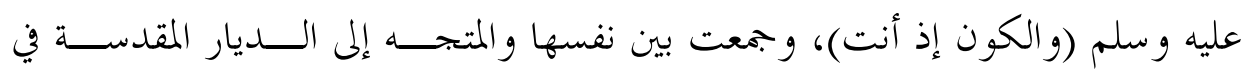

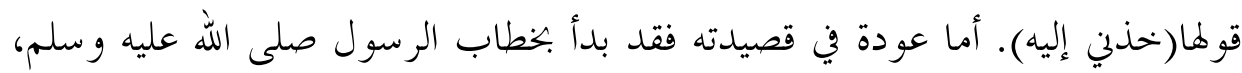

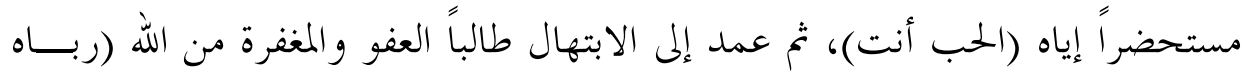

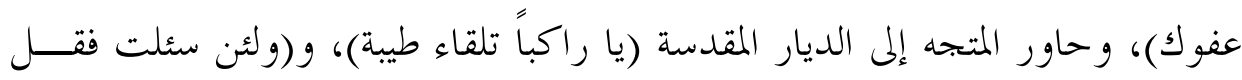

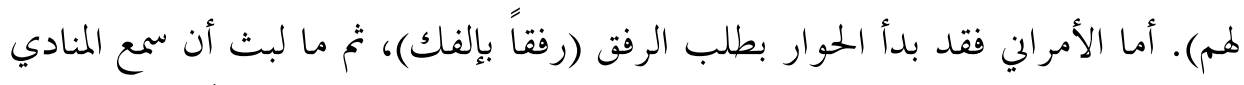

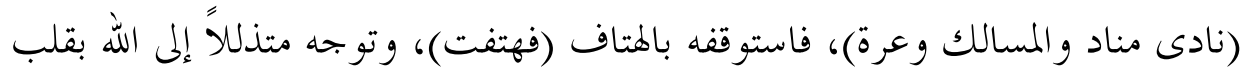

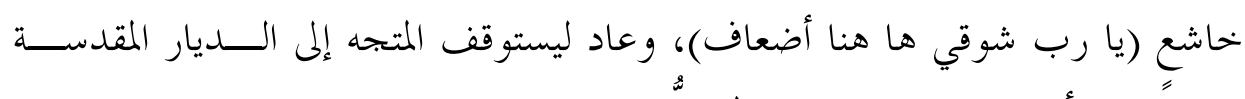
محاوراً إياه (أقرئه مني)، و و(ماذا عساك تبثٌهُ).

وهذا التنوع في الحوار مرتبط بتغير الضمير، فجاء أسلوب الالتفات واضـــحاً في

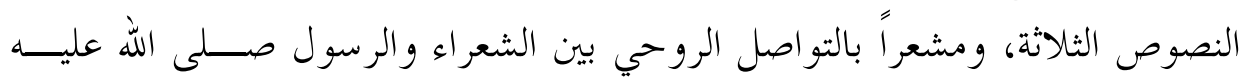

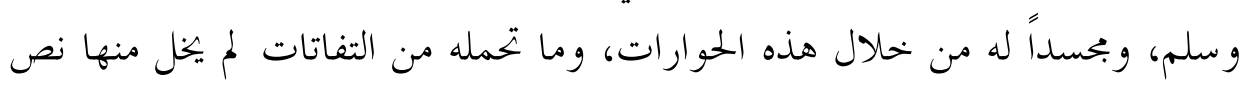
من النصوص المدروسة، فلم تعد النصوص بخيالاتها رومانسية ضيقة، وإنما رومانســية

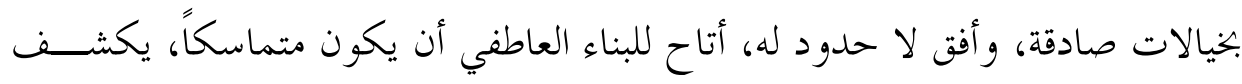

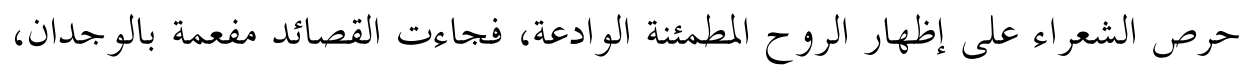

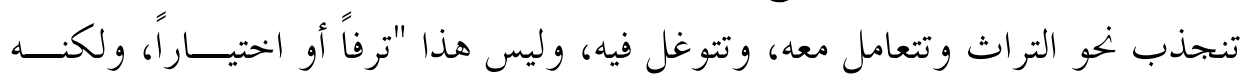

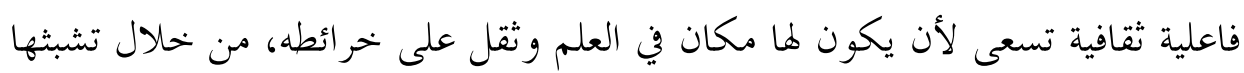




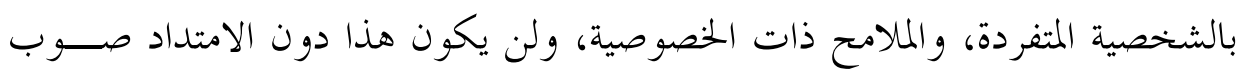

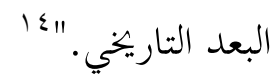

وهذا التوجه نخو التراث وظّف ليكون فاعلاً دون مغالاة؛ لأنَّ التجاوز والمغــالاة

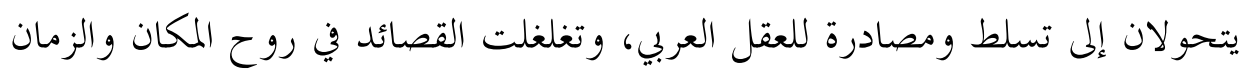

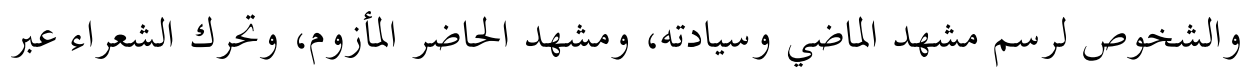

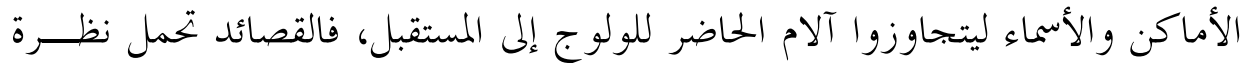

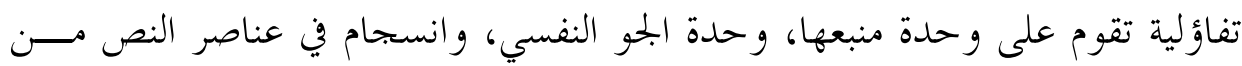

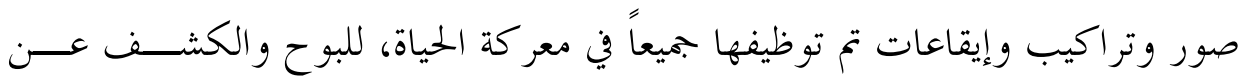

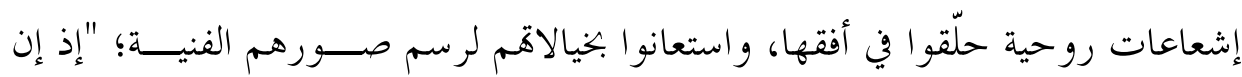

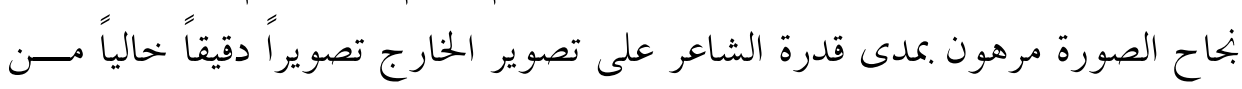
التعقيد، نابضاً بروح الأديب وقلبه."

\section{r. التشكيل البنيوي:}

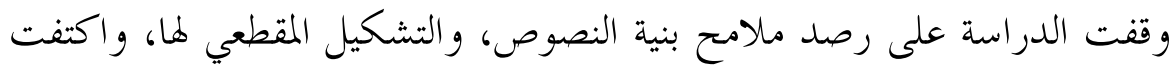

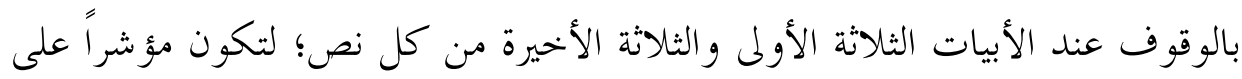

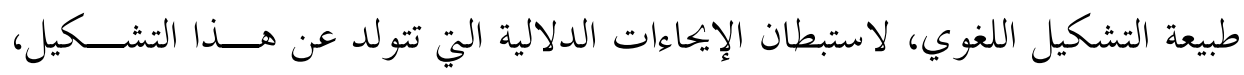

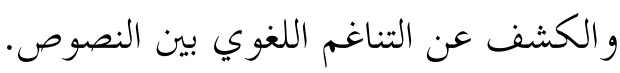

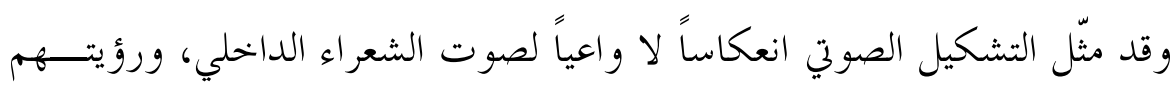
الإبداعية، وقد توزعت المقاطع في الأبيات على النحو التالي:

\section{قصيدة نبيلة الحطيب:}

$$
\text { عدد المقاطع من النوع القصير المغلق (ص ح ص): }
$$

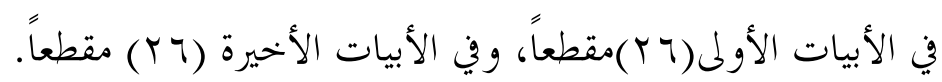

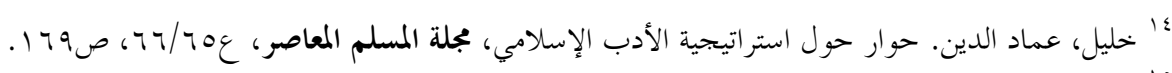

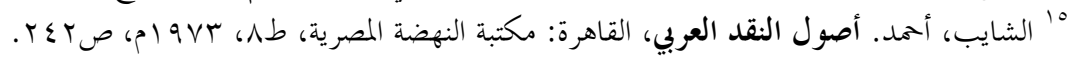


وعدد المقاطع من النوع القصير المفتوح(ص ح):

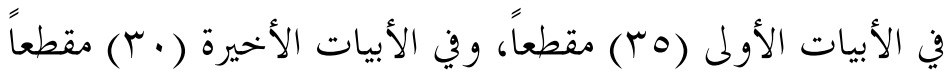

وعدد المقاطع من النوع الطويل المفتوح (ص ح ح):

في الأبيات الأولى (ع 1) مقطعاً، وفي الأبيات الأخيرة(9 (1) مقطعاً

في حين توزعت المقاطع في قصيدة عودة أبو عودة على النحو التالي:

عدد المقاطع من النوع القصير المغلق (ص ح ص):

في الأبيات الأولى (YV) مقطعاً، وفي الأبيات الأخيرة(Y) مقطعاً

وعدد المقاطع من النوع القصير المفتوح (ص ح):

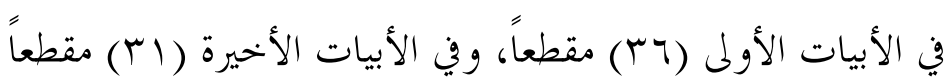

وعدد المقاطع من النوع الطويل المفتوح (ص ح ح):

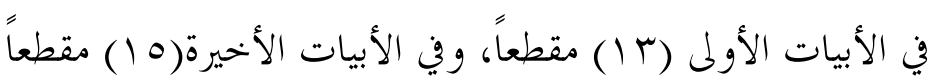

أما قصيدة حسن الأمراني، فقد توزعت المقاطع فيها على النحو التالي:

$$
\text { عدد المقاطع من النوع القصير المغلق (ص ح ص): }
$$

في الأبيات الأولى (IT) مقطعاً وين الأبيات الأخيرة (YT) مقطعاً.

$$
\text { وعدد المقاطع من النوع القصير المفتوح (ص ح): }
$$

في الأبيات الأولى (TYY) مقطعاً وفي الأبيات الأخيرة (Tب) مقطعاً.

وعدد المقاطع من النوع الطويل المفتوح (ص ح ح):

في الأبيات الأولى (ع () مقطعاً وفي الأبيات الأخيرة (1 (1) مقطعاً.

ومن هذا الاستقراء للبناء المقطعي يظهر شيوع المقطع القصير بنســبة مرتفعــة في

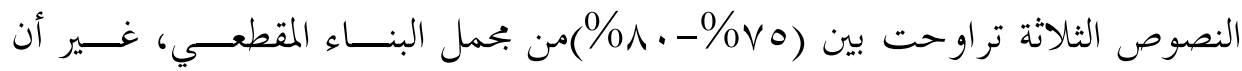




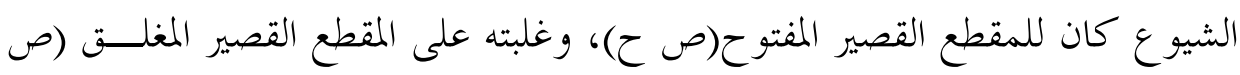
ح ص)، و انتهت الأبيات بالمقطع القصير المفتوح (ص ح ح).

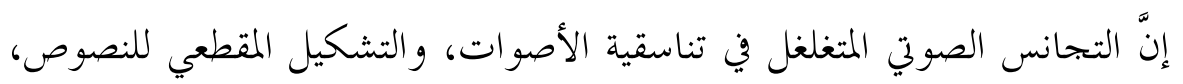

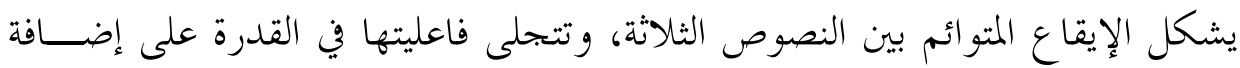

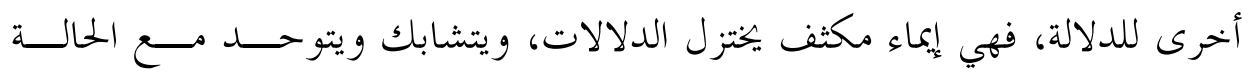

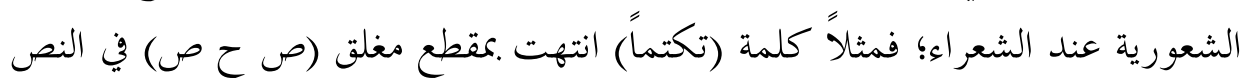

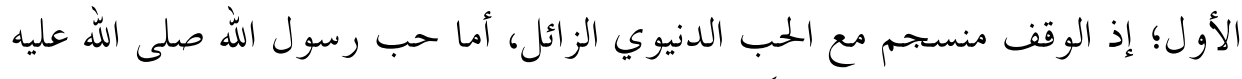

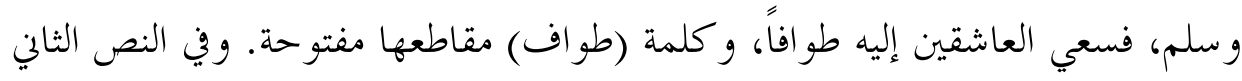

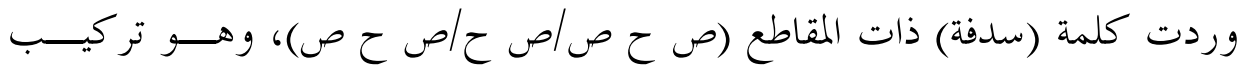
ينسجم مع الظلام الذي تدل عليه الكلمة.

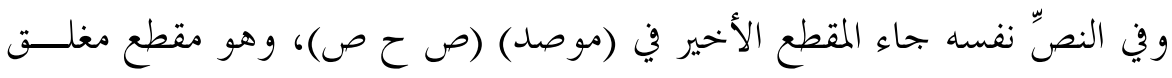

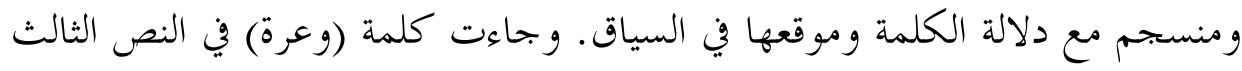
تنتهي .مقطع مغلق (ص ح ص) وهذا يتلاءم مع دلالة البيت: الشوق يودي، والجوى مــتلاف نادى منادٍ، والمســالك وعـــة:

و انتهت كلمة (خفاقة) مقططع مغلق (ص ح ص) منسجم مع المفردة؛ إذ إن بقــاء

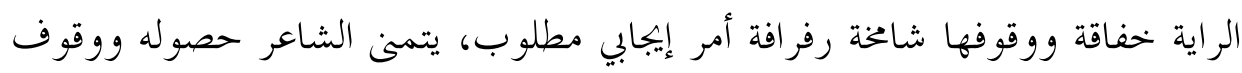
الكون عند تلك اللحظة.

ووقفة مع التنغيم المتمثل، في النصوص المكتوبة، في وجود علامات الاستفهام قد المدار

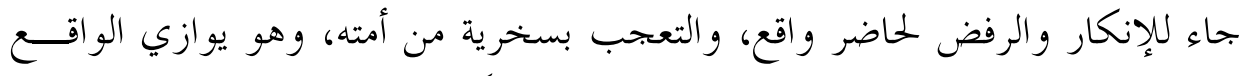

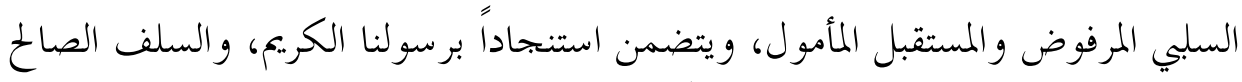

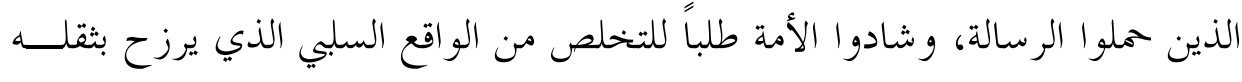

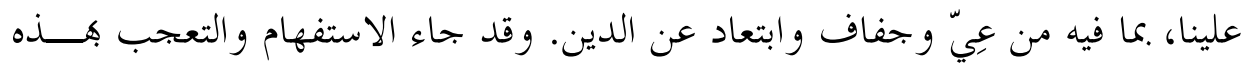




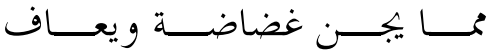

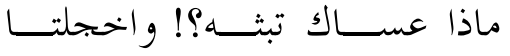

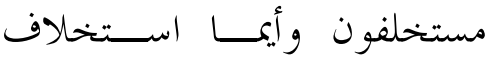

في عصرنا المســتخلفون تخلفــــوا

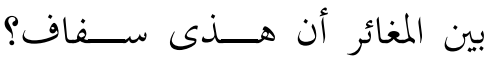

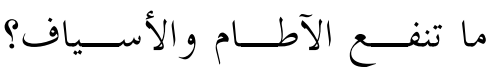

مــــاذا يضـــير النـــور في لألائـــــ

وإذا الجموى اخترق الحصون مظفراً

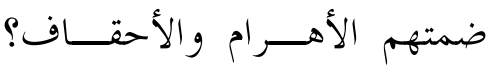

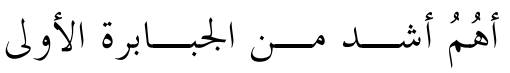

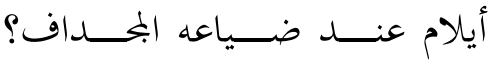

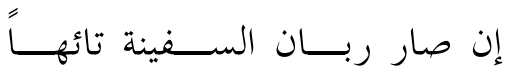

إنَّ ملمح التنغيم يتضح في قصيدتي نبيلة الخطيب و حسن الأمــــاني، ويشــير إلى

الإنكار وتوكيد النفي، وهو يتناسب والمقارنة والمقابلة بين ما هو متاح وغير متـــاح،

بين المرفوض والأثير إلى النفس. وقد حملت الأصوات و التشـــكيل المقطعـي والـــنم

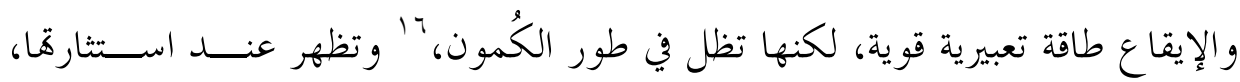

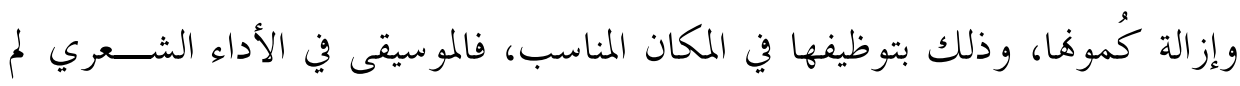
تكن مقصودة لذاها، بل أصبحت دالة على قيمة لغوية ومعنوية في النصوص، واستطاع الشعر اء استخر اج ما في الألفاظ من طاقات إيحائية وموسيقية، فانسابت مع الأشــــواق

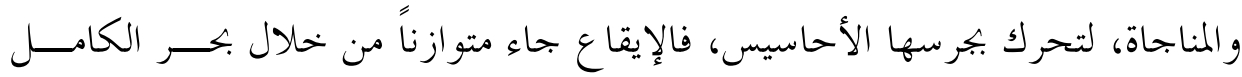

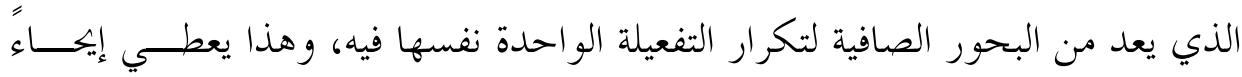
بالتوازن مع المعنى، ويستعمل لتعميق البنية الداخلية التي تبحث عن التوازن المفقـــود،

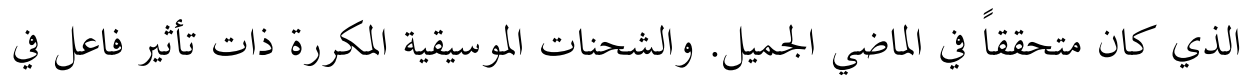
نفس المتلقي، ولهذا جاءت البنية الصوتية مندغمة بخصائص البنية العروضية مع البنيـــة

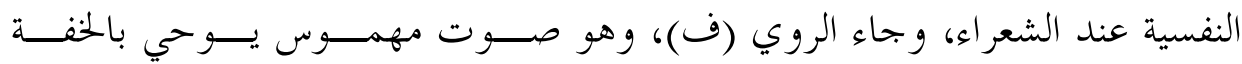

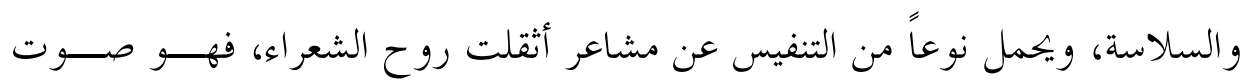
يرتبط بالانطلاق و الحر كية. 
إنَّ التكرار الفونيمي( صوت الحرف) الذي بتسد في القافية، قد أضفى بعداً نغمياً

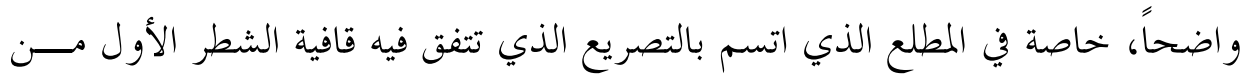
البيت الأول مع قافية القصيدة، فحقق الوزن والإيقاع مماثلة وزنية ومماثلة إيقاعية، وهما

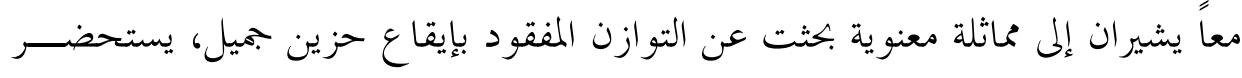
الماضي عبر التناص المعرفي معه، من خلال استدعاء رموز الماضي، ومحاولة اســتعادته، و هي البنية الدلالية الأساسية والمركزية في النصوص الثلاثة. وقد ساهم أسلوب التكرار

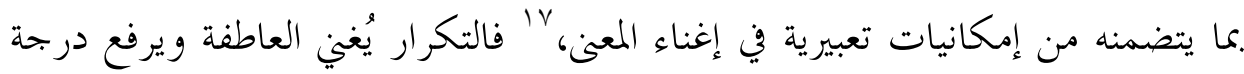

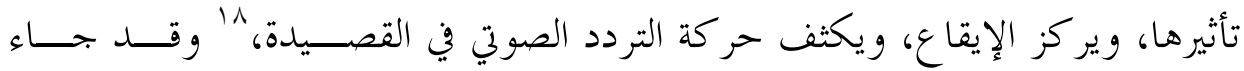
التكرار في القصائد الثلاث على النحو التالي: تكرار كلمة: في نص الشاعرة نبيلة: تكررت الكلمات الآتية: (الحبيب، الســيد، كنَّا، المستخلفون، ألَنْنا) و وي نص الشاعر عودة: تكررت الكلمات الآتية: (أنت، الحلب، فــيض، ربـــاه،

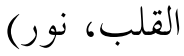

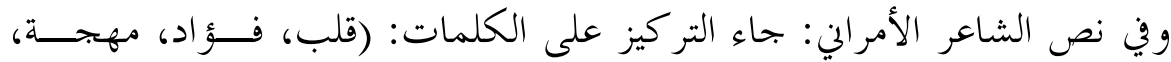

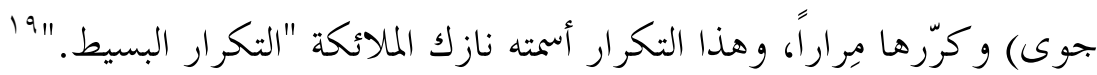

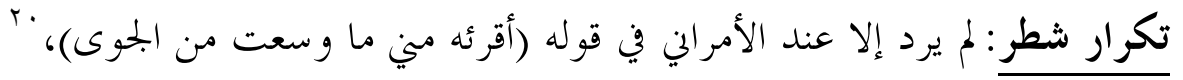

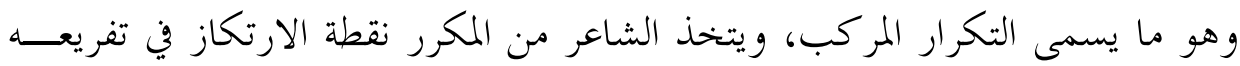

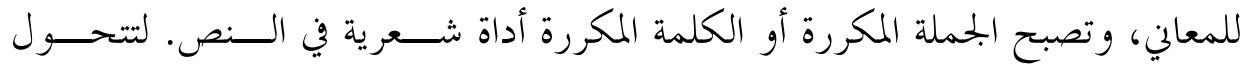

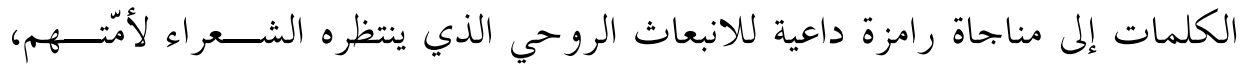
و كانت بعض صورها ابتهالية، مؤكدة على إحساس الشعراء وإصرارهم على البقـــاء،

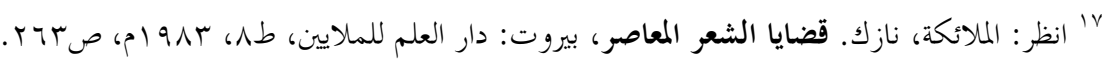

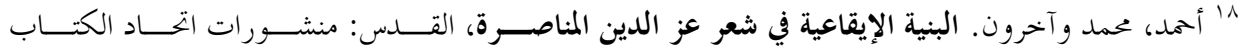




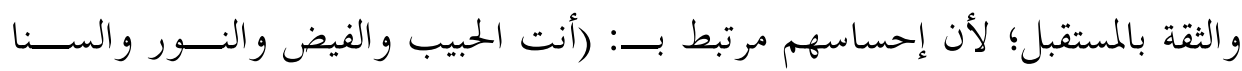

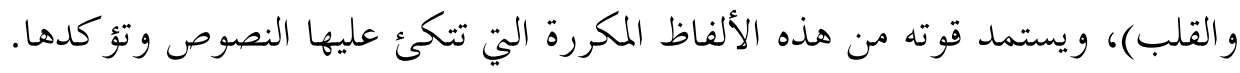

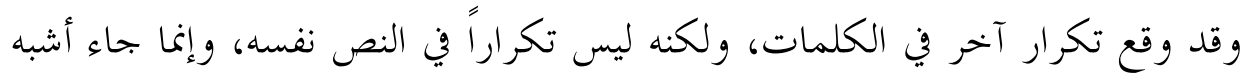

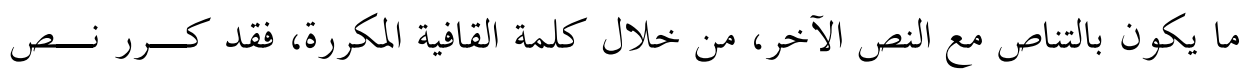

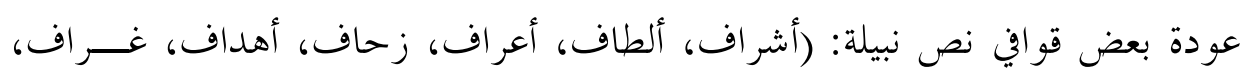
أطر اف).

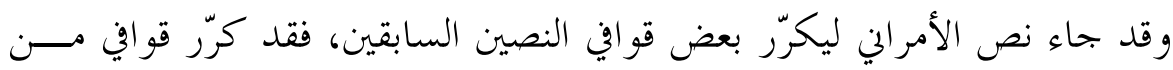

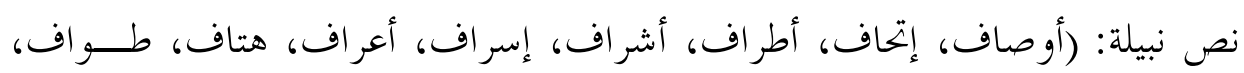

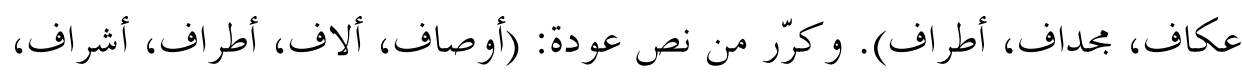

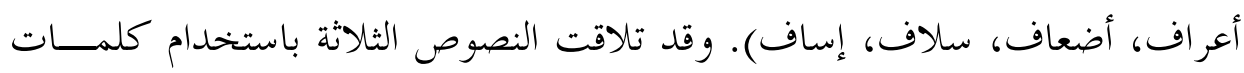
القافية (أطراف، أشراف، أعراف، ساف، إساف).

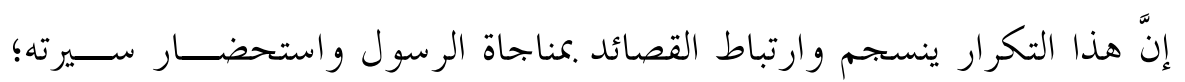

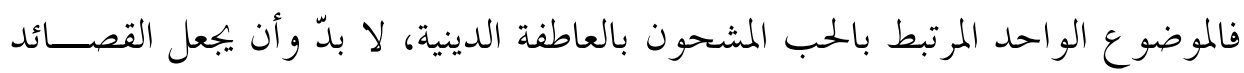

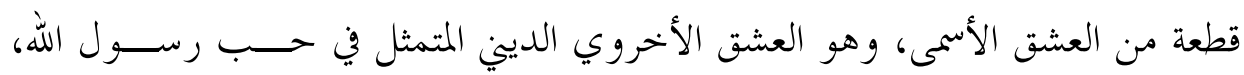

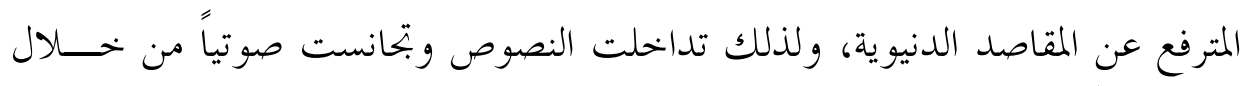

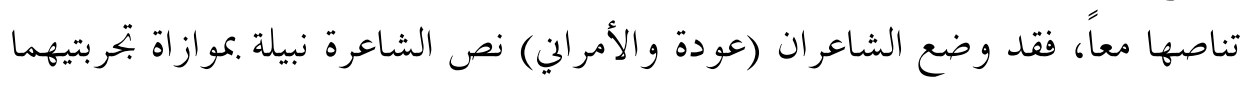

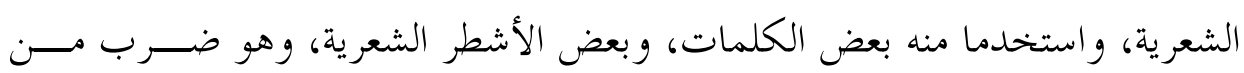

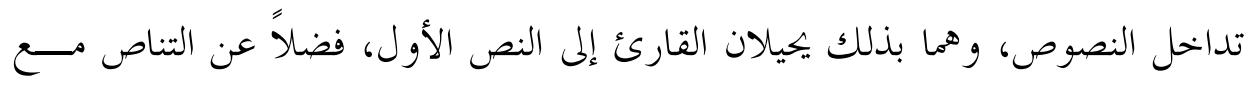

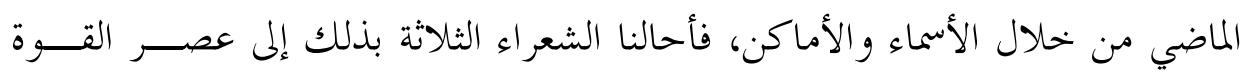

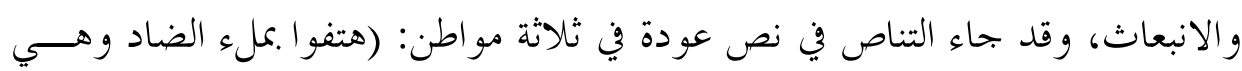

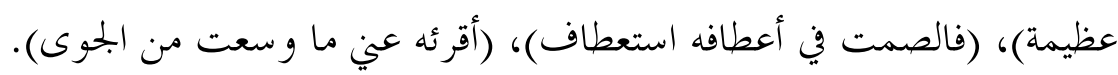

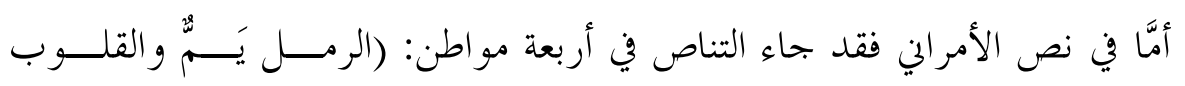

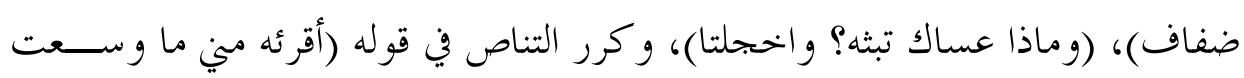

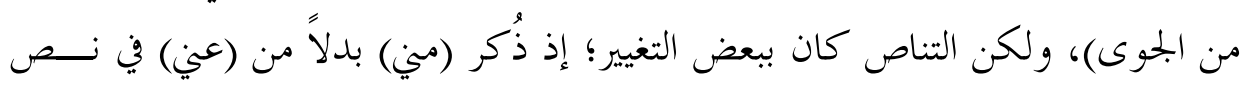




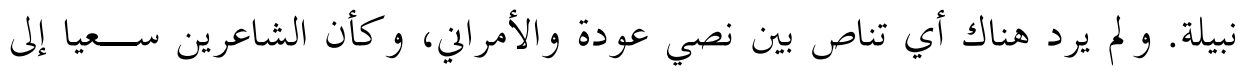

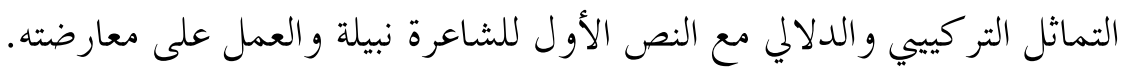
وقد اختارت الشاعرة نبيلة العنوان (أقرئه عني الجلوى)، وارتضاه الشاعران (عودة

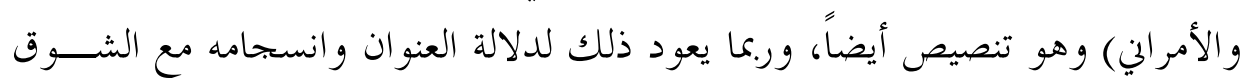

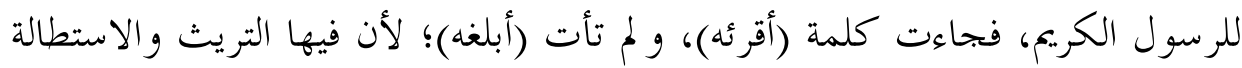

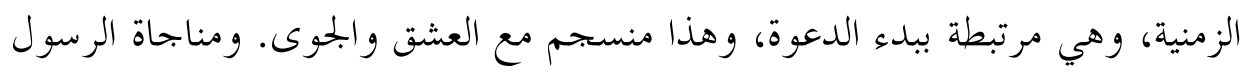

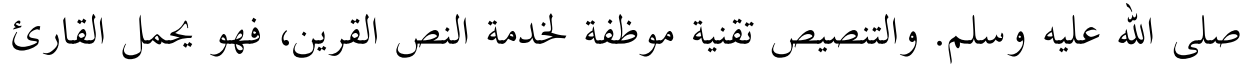

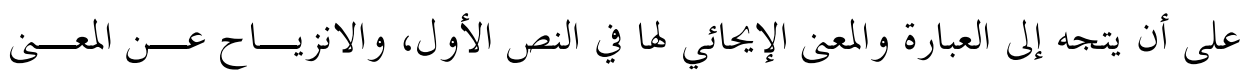

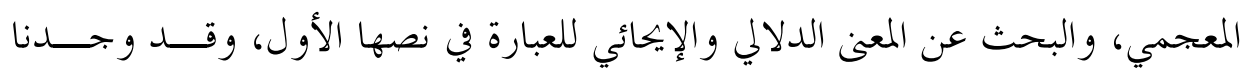

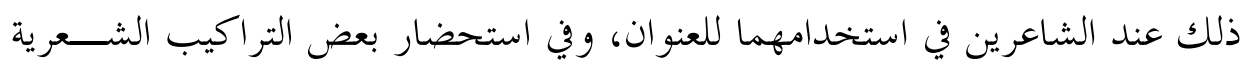

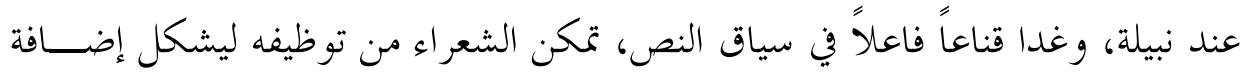

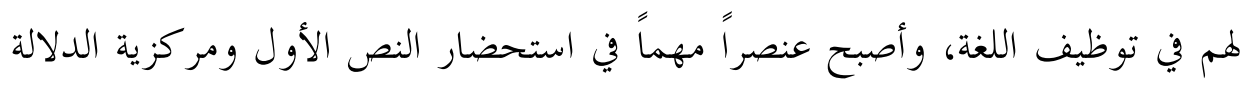

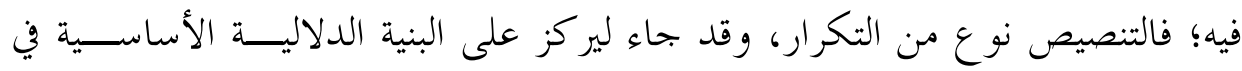

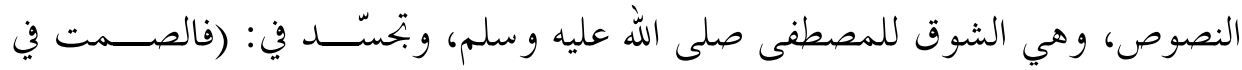

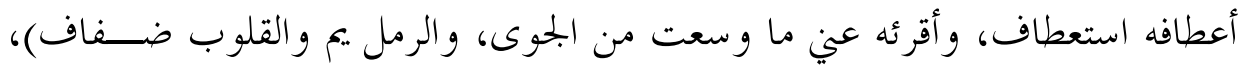

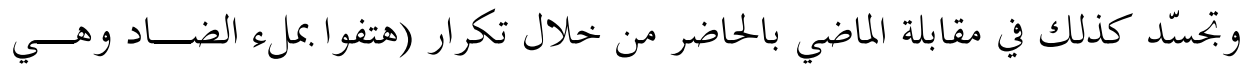

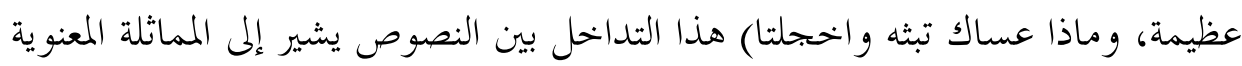
والعاطفية.

واتضحت المماثلة في أمر آخر وهو تنوع الأنساق اللغوية وتوزعها في النصوص، الأنساف

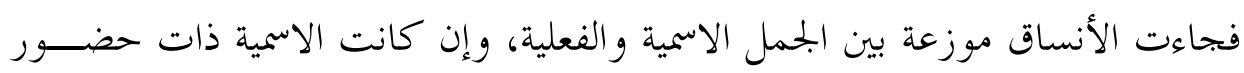

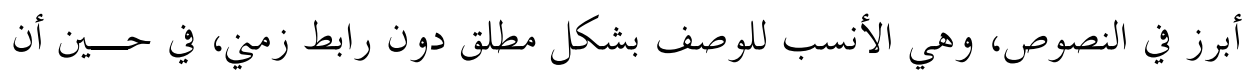

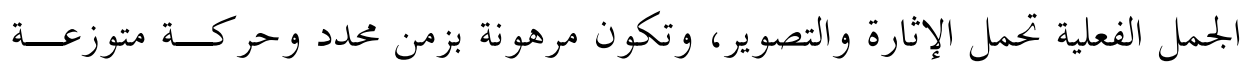

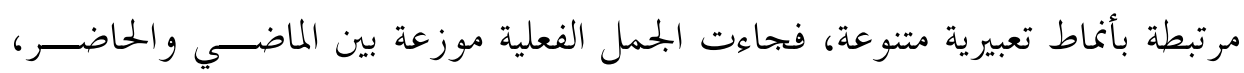

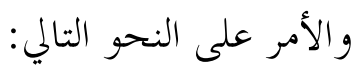




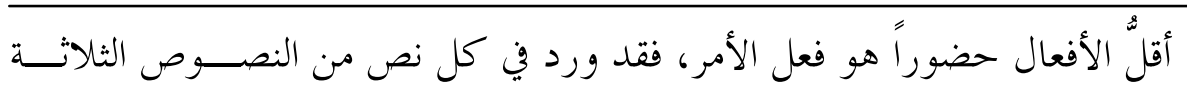

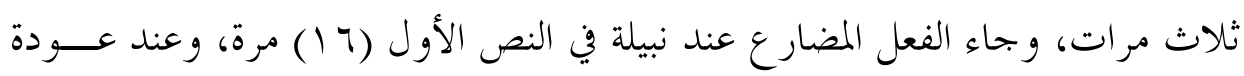

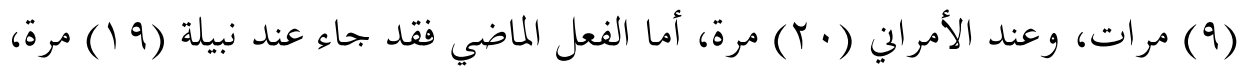

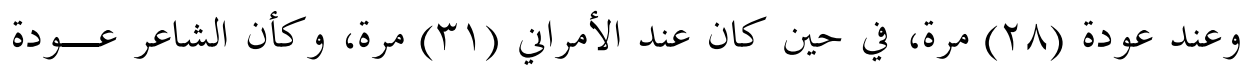
مستغرق في الماضي لا يحبذ الخروج منه، ولا يريد الالتفات للحاضر الأثيم، بينما كان التوازن في استخدام الفعل الماضي والمضارع في النصين الآخرين يوحي بأن الشــــاعرين يو اجهان الحاضر ويأملان في تغيره، من خلال تحسس الألم والبحث عن الدواء الناجع .4

إنَّ الأنماط التعبيرية جاءت متسقة مع مشاعر الشعراء، ومنسجمة مـــع القضــــايا

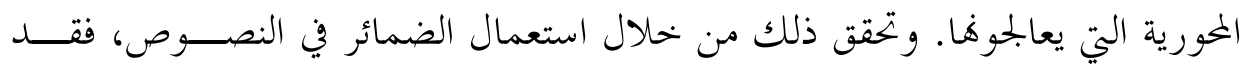
شاع في القصائد الثلاث استخدام ضمير المخاطب المفرد و الغائــب، مقابــل ضــــير

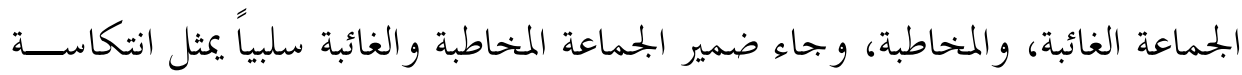
الحاضر، أما ضمير المخاطب فقد كان لاستحضار صورة الرسول، الحاضر دائماً وأبداً بروحه وسيرته، فهو المثل الأعلى الماثل أمام كل مسلم.

وتستمر الأنساق اللغوية في التنوع، وتمتد الدلالات عبر استخدام صور تعبيريـــة

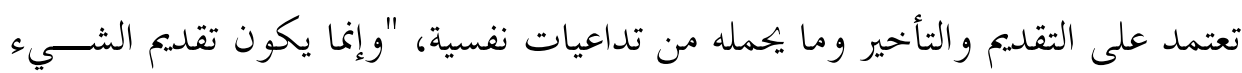

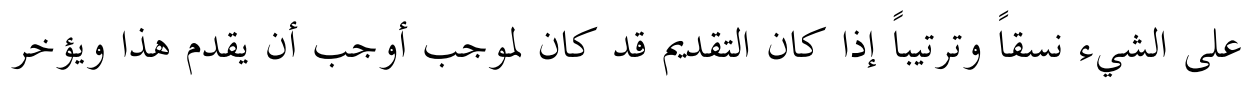

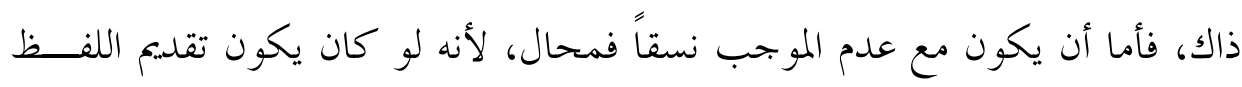

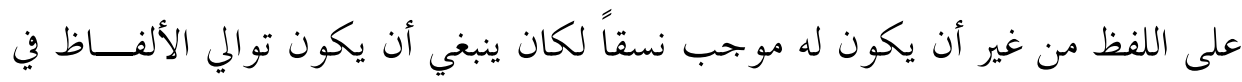

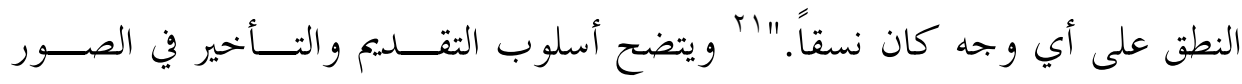

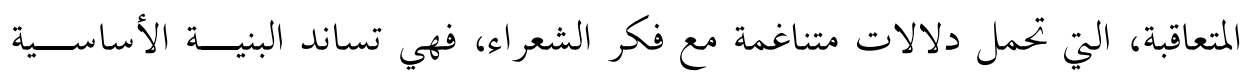
و المركزية في النصوص، ومن أمثلة ذلك عند نبيلة:

"r الجرجاني، عبد القاهر. دلائل الإعجاز، تحقيق: محمد رشيد رضا، بيروت: دار المعرفة، ب 91 (م) ص. بr. 
في غفوة الآصال يعتمل السنا، من حسنه تتفاخر الأخلاق والأوصاف، في عصرنا

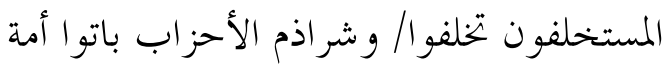

$$
\begin{aligned}
& \text { ومن أمثلته عند عودة: - من }
\end{aligned}
$$

الحب أنت و كلهم أطياف، هلوا من الورد العظيم حياهم، قد وســعت عبــــادك

رحمة، الحب أنت وغير بابك موصد، وعندك يكرم الأضياف.

أما تمثله عند الأمراني فكان على النحو التالي:

بي لهفة الأم الرؤوم، ياقوتة العرش امسحي، وإذا أنا قبلت طيب ترابه، يا ليت أني

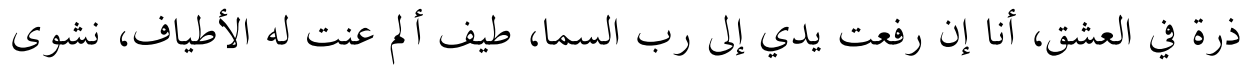
و في أحشائها نار اللظى، تفديه مين مهجة وشغاف، لو ركاف كان فينا خالد. هذه الصور الشعرية تحمل التقديم والتأخير في طياها، وهو يمثل نوعاً من الانزياح

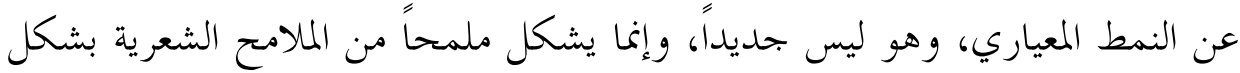
عام قديمه و حديثه، فهو قديم متجدد، وعلت درجة الانزياح في النصوص عما كــان

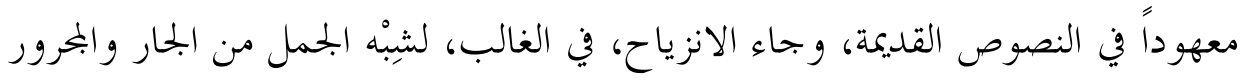

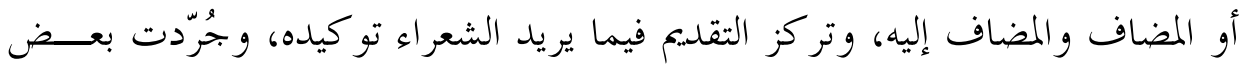

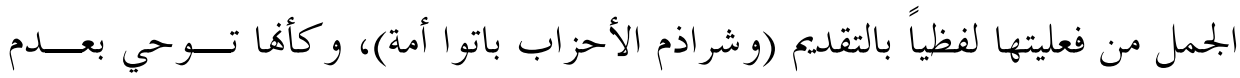

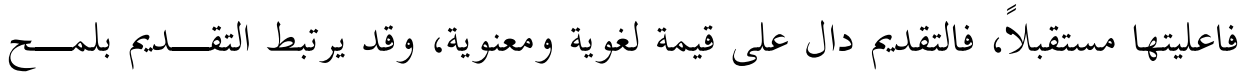

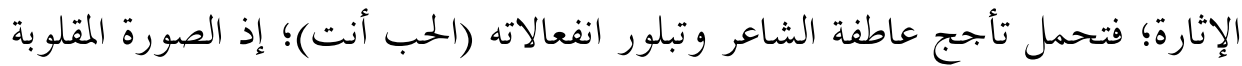

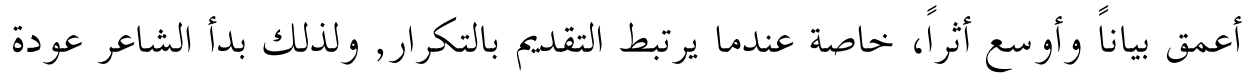

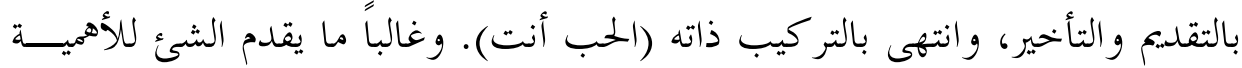

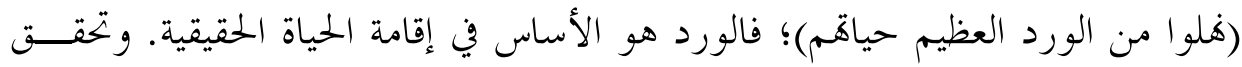

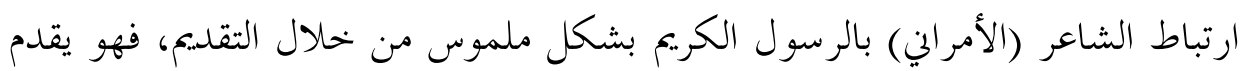

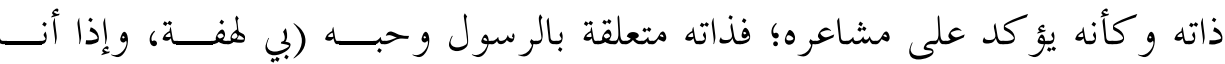

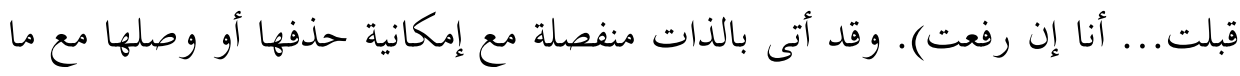

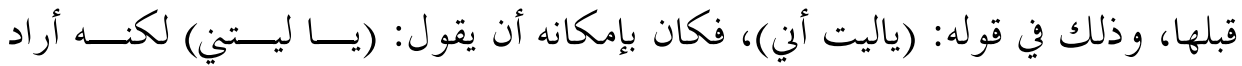


التوكيد على هذه الذات، ووفي قوله: (أنا إن رفعت)، كان يمكن أن يقول: (إن رفعت

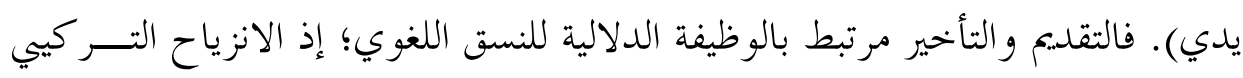

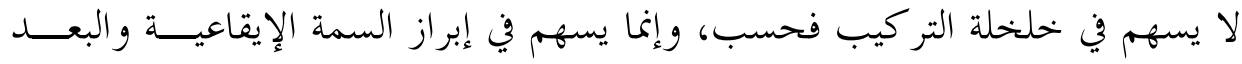
النغمي للقصيدة.

خاتمة:

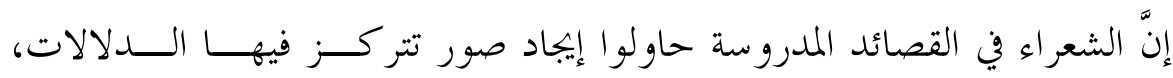
واستطاعوا التعبير عن الشجن النفسي باستخدام لغة تعبيرية مكثفة لتلك المشاعر، بدلاً

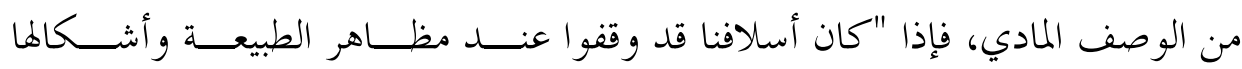
الخارجية، فإن قلوب شعراء اليوم تخفق صوب الأعماق و الجلذور لاكتشاف الــنفس، واكتشاف الإنسان والعالم..... صار فعالية جوهرية تتصل بوضع الإنسان ومســتقبله

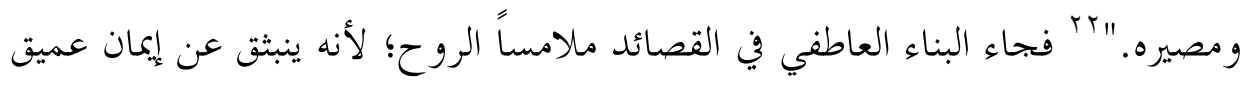

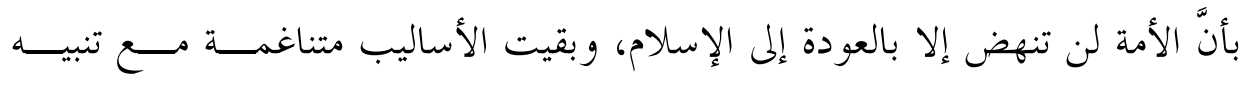

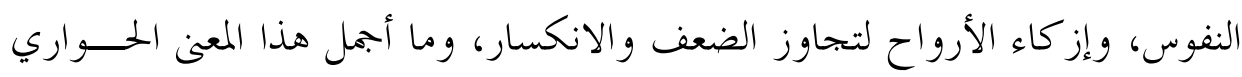

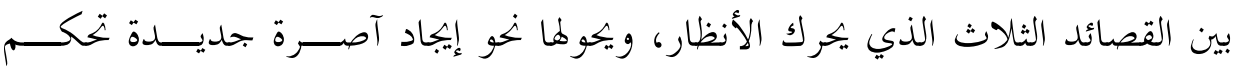
العلاقات الإنسانية، فتلاقت القصائد وتشاهت رغم الاختلافات بين أصحاها، فلم بند

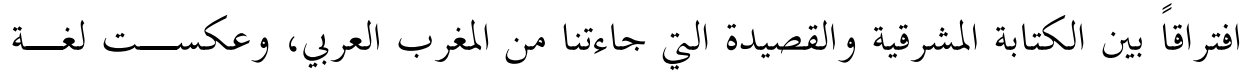

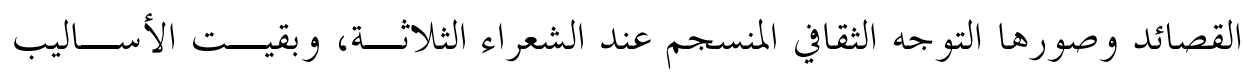

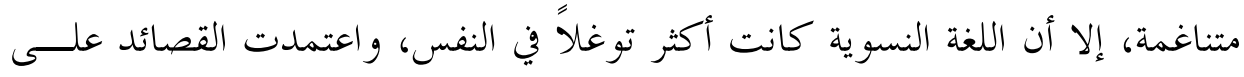
محاور لغوية تمثل بحموعات متكررة عن الأنساق اللفظية التي تومئ بالفكر الذي يركز

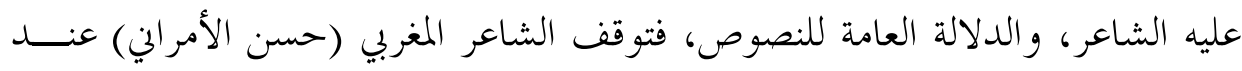

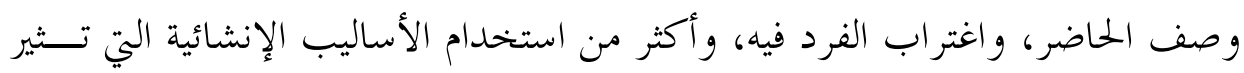
المتلقي، وتصور قتامة الحاضر، ورفض الشاعر له، في حين توقف الشاعران المشــــــيان (نبيلة الخطيب) و(عودة أبو عودة) عند الحاضر لمقابلته بالماضي و التحسر على أبحاده، 


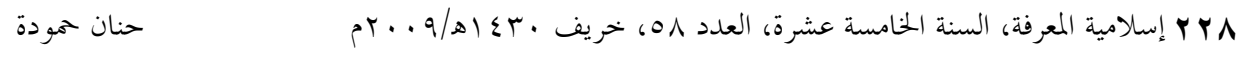
ولكنهم استطاعو ا أن يجعلوا قصائدهم مشحونة بالتوترات النفسية المتكئة على انفساح في الرؤية الفنية، وهذه الرؤية الفنية المعتمدة على مشاعر فياضة صادقة، منحت الشعراء

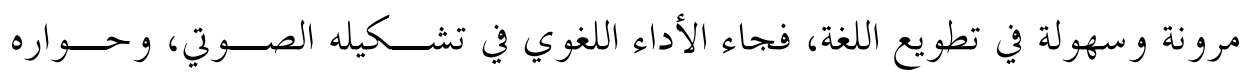

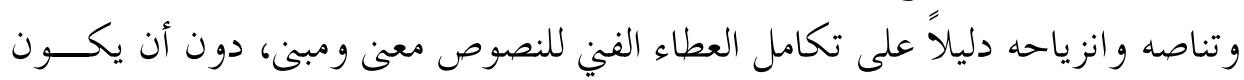

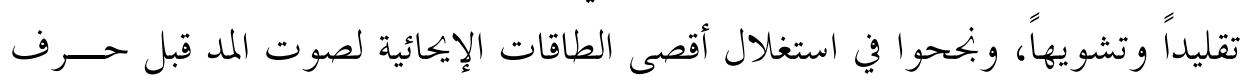

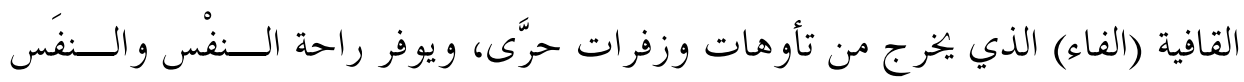

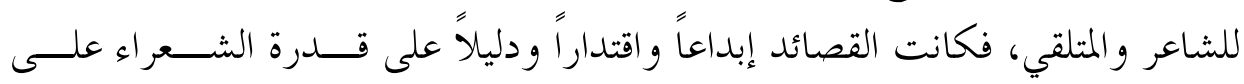
المزاو جة بين طاقاهم الإبداعية وبتارب الآخرين. 


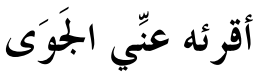

نبيلة الخطيب

والكون إذ أنت الحبيب شـــاف

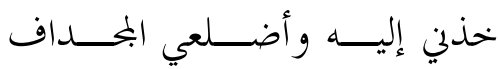

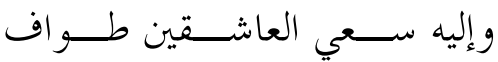

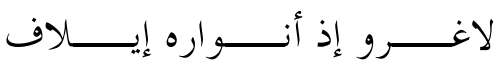

ولشجوه في الخافقـــات هتـــاف

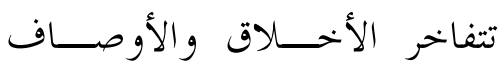

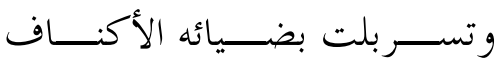

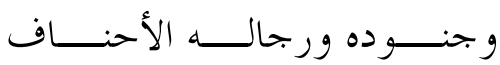

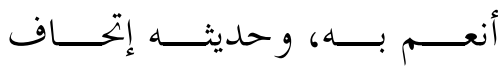

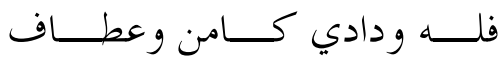

و الطرف من شـــوق بـــهـ ذراف

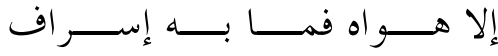

فالصمت في أعطافه اســتعطاف

قلب الرمـــال تــبرعم الأفيـــاف

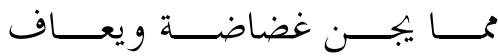

مستخلفون؟! وأيمـــا اســتخلاف

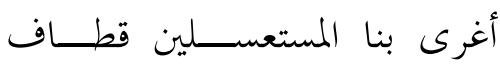

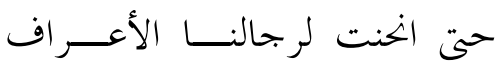

و اليوم من دون الورى أطـــــاف

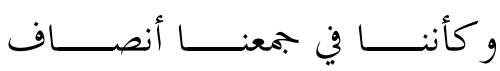

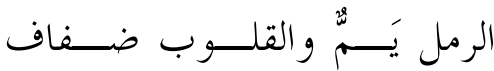

الموج مور دمي وشوقي مـــركي

يسعى الحبيب إلى الحبيب تكتماً

فمن الفجاج الشـاردات توافـــو التوا

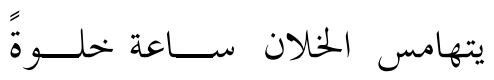

هو سيد الخلق الذي من حســـنه

السيد القرشــي غرتـــهـ الســـــا

الزاهرون الطــــاهرون جــــدوده

تسبيحه القـــرآن يكيــي ليلــهـ

أقرئه عني ما وسعت من الجلـــوى

القلب ســـربله الحـــنين لنــوره

ما زاد عن حجم الإناء مطفـــف إن سربلتك طيو به قف صــــامتاً

ولعل دمعك حين يهمي موقظًا

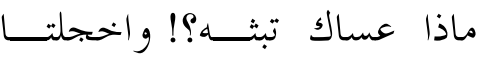

في عصرنا المستخلفون تخلفـــو !

ذبنا على عرش التقـــادم و الخنـــا

كنا بلجنا الصبح في غسق الدجى

كنـــا صــــدور العـــالمين أئمـــــة

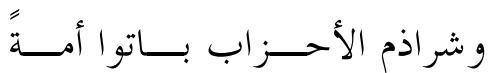




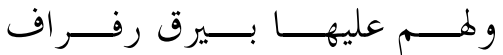

وتمجهر

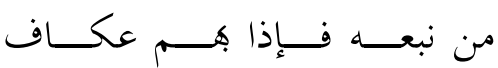

بين المغائر أن هذي سفســاف؟!

وسواهم تحت الثـــرى زحــــاف

ليمور في الأسحار وهو رعــــاف

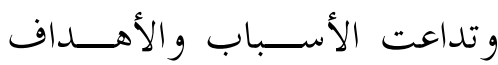

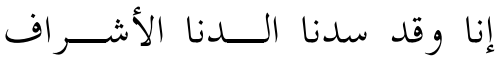

شقوا العو اصم كل عاصمة لهــم

الناس في كنف الحيـــاة تعجهـــم

إلا الذين قد استقو ا فيض الســــا

ماذا يضـــير النــور في لألائــه،

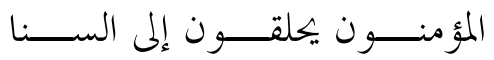

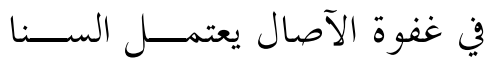

حتى إذا ائتلقت غـــلالات المـــن

قلنا بمل الضاد -وهي عظيمة-: 


\section{أقرئه عني الجوى}

\section{عودة أبو عودة - موة}

هيهات تبلغ قــدرك الأوصــاف وبك الرجاء إذا القلوب عجاف

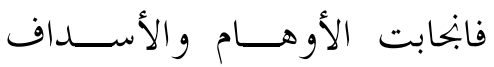

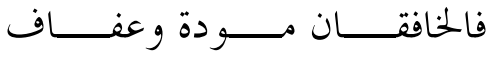
تربو هـــــ الجرعــاء و الأفيــاف فهم بنــورك ســادة أشـــــاف

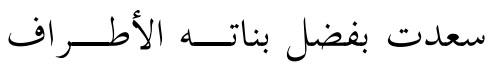

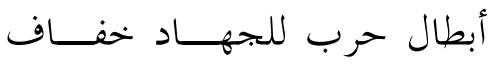
طـــه صــالاقم وهـــود وقـــــاف فاستحكم الإتلاف و الإســفاف ودرد

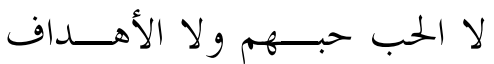
واليوم نائل قصــــهم وإســـاف واليوم وردهم صدى وجفــــاف

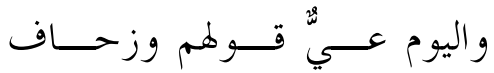

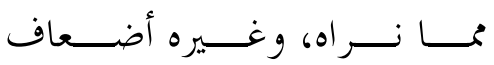

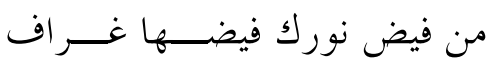
نحو الرحال الأنفــس المهيــاف

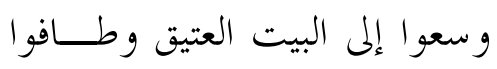

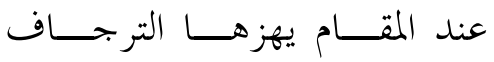

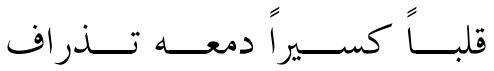

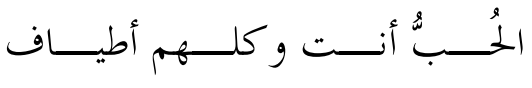

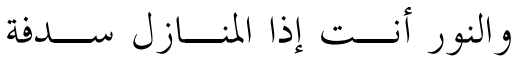
أرسلت نورك في الأنــام مبشـــــاً سارت مع الشمس البصائر و الهدى والأرض ذات العرض فيض غـــامر

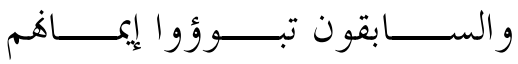

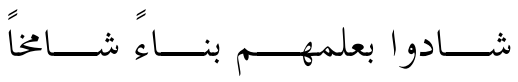
إن أشرقت شثــس النـــهار فـــإذهم

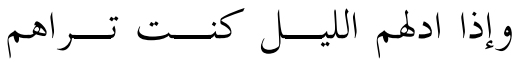
لكن خلفهم أضــاعوا رشـــهم

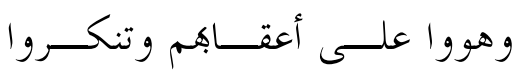
بالأمس كـــان الله نـــور قلــــهم هلوا من الورد العظــيم حيـاتم

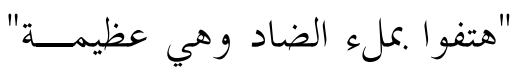

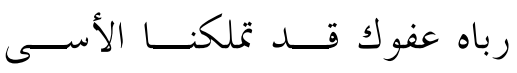

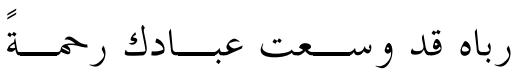

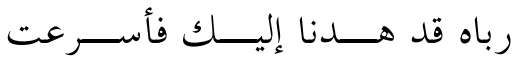
تاقت نفوسهم رإيك وهي تَهُهُّـبـب

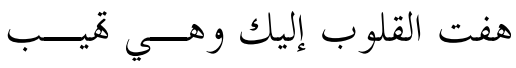

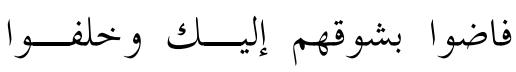


حنان حمودة

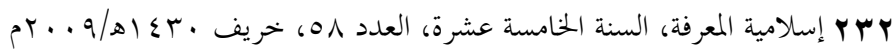

تذوي، و وعند جلالك الألطــاف

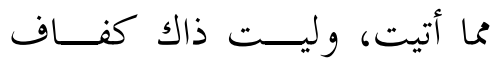

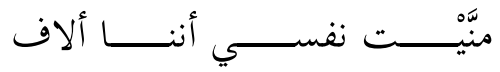

"فالصمت في أعطافه استعطاف"

إن الجوى للعاشــقين ســلاف

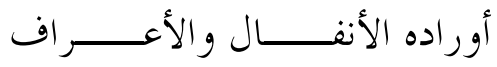

عني، وعندك يكـــرم الأضــياف
يا نور كل النــور هــــي شمعــة

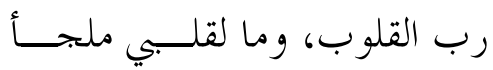

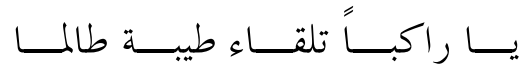

إن جئت فاصمت في حماه تخشـــاً

"أقرئه عني ما وسعت من الجــــوى"

ولئن سئلت فقل لهم صــب ذوي

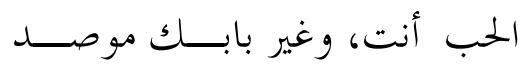




\section{أقرئه عني الجموى}

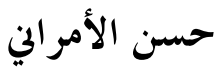

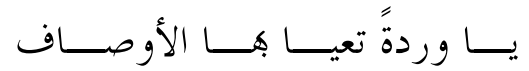

والشوق قد تضنى بـــه الأعطــــاف

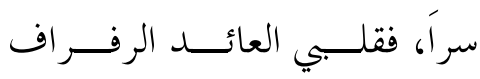

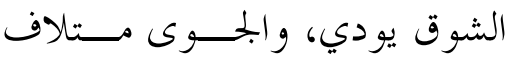

جاءوا الجوى، إن الجوى إتحـــاف

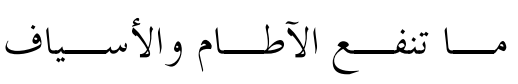

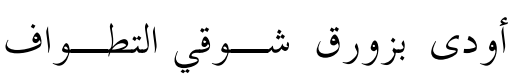

خفيت ويخفى النخل والصفصاف

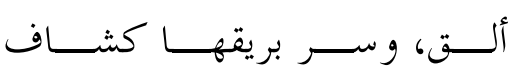

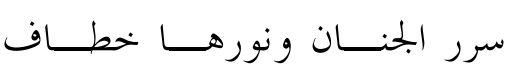

هاجت، فأفضى بـالجوى الآلاف

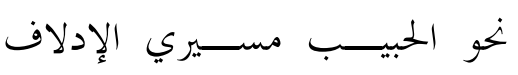

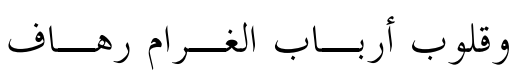

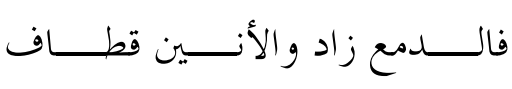

(الرمل يم، و القلـــوب ضـــــاف)

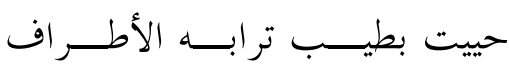

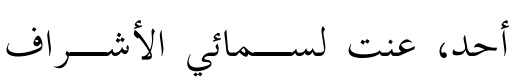

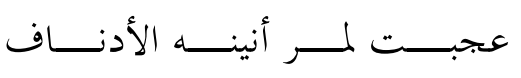

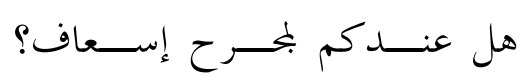

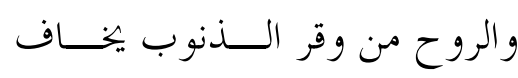

رفقا بإلفــك فــالجوى إيــلاف

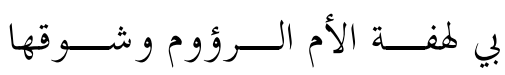

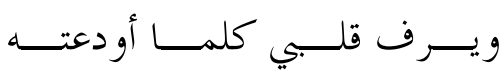

نادى منــاد و المســالك وعــــة:

فهتفت: نعم مطارف الشهداء إذ مأ مأد

وإذا الجوى اخترق الحصون مظفراً

ياقوتة العرش امسحي تعبي فتـــــ

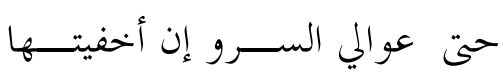

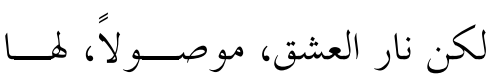

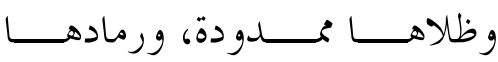

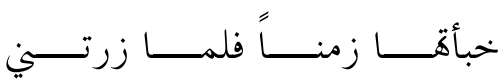
فتخذت مركبتي ســناها هاديـاً

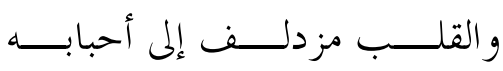

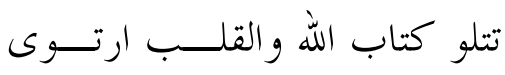

ذاقوا على البعد الجوى فتواعدوا:

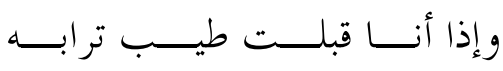

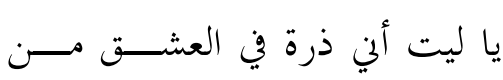

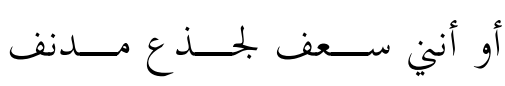

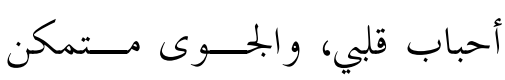
أنا إن رفعت يدي إلى رب السما 
بالعفو تنشــــر ظلـــه (الأعـــــاف)

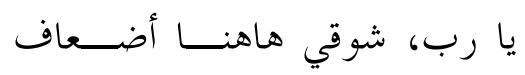

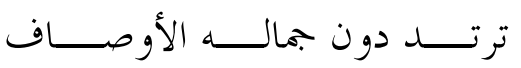

الشوق أغلب، و القلوب ضــــعاف

سكرى و لم تلعب هـــن ســلاف

هتف الفؤاد به، وطــــاب هتــــاف

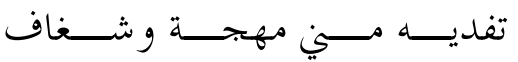

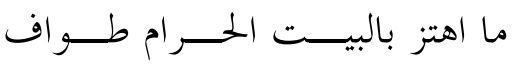

وعلى القلوب من الذنوب غلاف

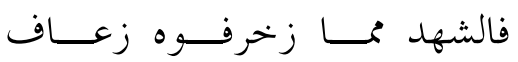

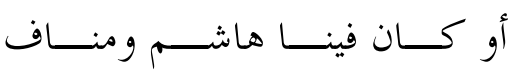

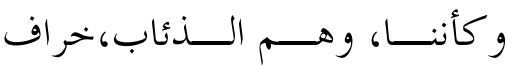

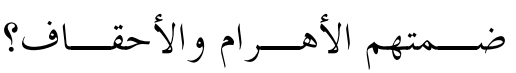

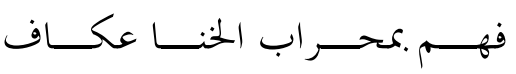

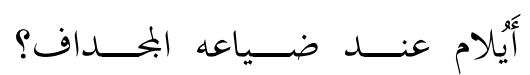

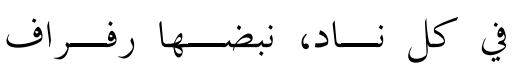

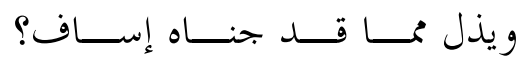

و القلب مضطرم الجوا انب خشــيةً

ويرف قلــي خاشـــاً متـــلالًا

طيف ألم عنـــت لــــه الأطيـــاف

خطت على الأبواب أقلام الجوى:

نشوى وفي أحشائها نار اللظـى لـى

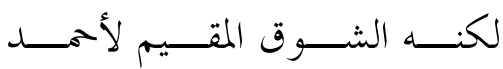

أقرئه مني ما وسعت من الجـــوى

أقرئه مين ما وسعت من الجــــىى

(ماذا عساك تبثــهـ و اخجلتـــا)

شاهدت وجوه القوم،من قيل الخنا

لو كان فينا خالد ما استأســدوا

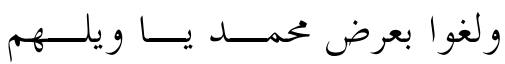

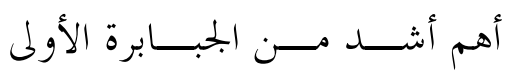

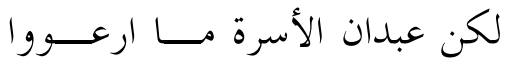

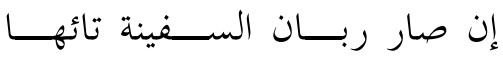

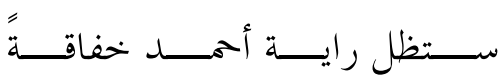

وتخر نائلـــة، هــــوت أعلامهــــا، 